\title{
Audit Market Concentration and Audit Fees: An International Investigation
}

\begin{abstract}
Several large auditor consolidations in the late 1980s-early 1990s, along with Arthur Andersen's collapse in 2001, facilitated global audit market concentration. Subsequently, regulators have expressed serious concern over the potential detrimental effects of this concentration, including cartel pricing. This study investigates the association between audit market concentration and audit fees. Using a large sample from 17 countries, our study yields three principal findings. First, consistent with regulators' concern, a significantly positive association exists between market concentration and fees. Second, the country-level legal regime changes this association dramatically: while significant and positive in countries with a weak legal regime, the association weakens and eventually becomes negative as the legal regime strengthens. Third, these associations are more pronounced among clients of non-Big 4 auditors than those of Big 4 auditors. These findings provide regulators and other stakeholders with important insights into the effects of audit market structure on audit pricing.
\end{abstract}

Keywords: Audit market concentration, audit fees, legal regime. 


\section{INTRODUCTION}

Several large auditor consolidations that occurred in the late 1980s and 1990s dramatically increased audit market concentration, not only in the U.S. but also in other countries. ${ }^{1}$ The collapse of Arthur Andersen in 2001 further increased the dominance of the remaining so-called Big 4 auditors. Moreover, the enactment of the Sarbanes-Oxley Act (SOX) and the subsequent establishment of the Public Company Accounting Oversight Board (PCAOB) motivated many small auditors to exit the U.S. audit market for listed clients, thus further aggravating audit market concentration (DeFond and Lennox 2011). It seems likely that the introduction of similar regulations in other countries during the mid-2000s $\mathrm{s}^{2}$ resulted in comparable consequences.

The above changes in the audit environment have attracted much attention from regulators, accounting researchers, and other stakeholders. ${ }^{3}$ In response, pursuant to SOX, the U.S. Congress mandated the Government Accountability Office (GAO; formerly the General Accounting Office) to study the effect of auditor consolidations on the audit market. Subsequently, GAO conducted two studies (i.e., GAO 2003, 2008) concerning auditor competition, audit fees, and audit quality. In the U.K., the Department of Trade and Industry and the Financial Reporting Council also commissioned a similar study (Oxera 2006). Regulators continue to be concerned that oligopolistic market dominance by a few large auditors might diminish competition in the audit market, which, in turn, may cause cartel pricing and, eventually, lead to deterioration of audit quality. For example,

\footnotetext{
${ }^{1}$ See, for example, Gilling and Stanton (1978) for Australian evidence, Christiansen and Loft (1992) for Danish evidence, Bigus and Zimmermann (2008) for German evidence, Johnson, Walker, and Westergaard (1995) for New Zealand evidence, Moizer and Turely (1989), Pong (1999), and Abidin, Beattie, and Goodacre (2010) for U.K. evidence, and Danos and Eichenseher (1982) for U.S. evidence on changes in audit market concentration worldwide. ${ }^{2}$ See Choi, Choi, Hogan, and Lee (2013) for examples of the introduction of similar regulations in other countries.

${ }^{3}$ For example, the Secretary of the U.S. Treasury, Henry Paulson, stated that 'The big four [accounting] firms dominate the industry in terms of revenues and professional staff. ... The current situation forces us to ask questions about the industry's sustainability and effectiveness...' (U.S. Treasury 2006).
} 
GAO (2008) specifically notes that dominant auditors could use their market power to charge high fees, while providing low-quality audit service.

After lengthy investigations, however, GAO (2003) suggests that regulatory concerns about the alleged adverse consequences of audit market concentration seem ungrounded. GAO (2003) reports that inflation-adjusted audit fees remained flat or even decreased slightly in the 1980s and had been increasing only since the late 1990s. It also contends that the increase in fees was largely attributable to environmental changes, including audit standards changes and legal reforms that occurred in the late 1990s and early 2000s, rather than to increased audit market concentration, and concludes that the audit market appears to remain competitive regardless of its increased concentration. Summarizing, GAO (2003) states that the effect of audit market concentration on audit fees and audit quality is inconclusive. GAO (2008) reiterates the same conclusion. Subsequent studies have also yielded conflicting results on the issue (e.g., Boone, Khurana, and Raman 2012; Choi, Kim, and Raman 2016; Francis, Michas, and Seavey 2013; Huang, Chang, and Chiou 2016; Kallapur, Sankaraguruswamy, and Zang 2010; Newton, Wang, and Wilkins 2013). In summary, despite regulatory concerns, it is not yet clear whether high audit market concentration leads to high audit fees and poor audit quality. Thus, the association between audit market concentration and audit fees/quality remains an important, but unresolved, question for regulators, the auditing profession, audit clients, and academic researchers. GAO $(2003,2008)$ calls for further research on the issue.

This study aims to investigate the issue of audit market concentration, focusing on its impact on audit fees. Specifically, we investigate the following three distinct, but interrelated, questions: (1) Is audit market concentration associated with audit fees in an international setting? (2) Does the strength of a country's legal regime influence the association between audit fees and audit 
market concentration? (3) Does auditor type, namely Big 4 versus non-Big 4 auditors, influence the aforementioned associations?

In this study, we focus on audit fees, rather than audit quality. It is because the former issue is not sufficiently covered by prior studies compared to the latter despite audit clients and auditors having greater interest in the former than the latter. For example, based on a survey of 250 Fortune 1000 firms, GAO (2003) reports that respondents perceive audit quality to remain unchanged after auditor merger, but worry about possible audit fee increases post-merger. However, we are aware of only three prior studies that have directly investigated the influence of audit market concentration on audit fees with a large sample. While Boone et al. (2012) report that audit market concentration is associated with lower audit fees in the U.S., Huang et al. (2016) report that this concentration is associated with higher audit fees in China. In contrast, Bandyopadhyay and Kao (2004) do not find a significant association in the Canadian municipal market. ${ }^{4}$ Thus, these three studies using three different countries' data provide conflicting results, making it difficult to draw any definitive conclusions. ${ }^{5}$

Given that clients have strongly criticized skyrocketing audit fees since the collapse of Arthur Andersen and the enactment of SOX (Ghosh and Pawlewicz 2009), for which they blame

\footnotetext{
${ }^{4}$ Bandyopadhyay and Kao (2004) document a significant positive association in one analysis. However, because the significant association is only marginal (i.e., significance at the 10 percent level in one-tailed test in their Panel A, Table 2) and the other two tests yield insignificant results, we interpret their study as reporting insignificant results.

${ }^{5}$ There are a few other studies that investigate the change of audit fees after large auditor mergers (e.g., Feldman 2006; Ghosh and Pawlewicz 2009; Ivancevich and Zardkoohi 2000; Menon and Williams 2001; Pong and Burnett 2006; Sullivan 2002). Although audit market concentration increases as a result of the mergers, it is likely that other environmental changes also occurred at the time of the mergers. Therefore, it may be difficult to attribute the audit fee increases, if any, simply to the increased audit market concentration. Separately, Pearson and Trompeter (1994) investigate the association between audit market concentration and audit fees with a limited number of samples that belong to the life and health insurance industry and the property and casualty insurance industry. Alternatively, Cairney and Stewart (2015) and Numan and Willekens (2012) use audit market concentration as a control variable in their analyses on the determinants of audit fees. While Numan and Wilekens (2012) document a negative coefficient on the audit market concentration, Cairney and Stewart (2015) report mixed results. Thus, the findings in these two studies are also mixed at best. We do not specifically discuss these two studies because the concentration is used only as a control variable in their analyses.
} 
cartel pricing of the remaining Big 4 auditors (Kersnar 2008), it is both interesting and important to investigate the effect of audit market concentration on audit fees. In sharp contrast to the clients' complaints and the regulators' concerns (e.g., GAO 2008), Danos and Eichenseher (1982) and Pearson and Trompeter (1994) argue that concentration enables auditors to accumulate expertise in handling complex audits, which leads to economies of scale. Similarly, Yardley, Kauffman, Cairney, and Albrecht (1992) argue that dominant auditors can develop audit efficiency, which, in turn, enables them to lower audit fees. Therefore, with these two conflicting views, it is premature to attribute the audit fee increase in the U.S. around 2002 to increased concentration (or reduced competition) in the audit market after the collapse of Arthur Andersen.

As a second research question, we investigate how the strength of a country's legal regime influences the association between audit market concentration and audit fees. Prior studies report that the country-level legal regime influences auditor behaviors in various settings (e.g., Choi and Wong 2007; Fan and Wong 2005; Francis et al. 2013; Francis and Wang 2008; Gul, Zhou, and Zhu 2013; Khurana and Raman 2004). A strong legal regime promotes fair competition and prevents auditors from engaging in any collusive activities (Waked 2016). Thus, the fee-increasing effect of collusive behavior should be reduced in countries with strong legal regimes, while the fee-decreasing effect of economies of scale is unlikely to vary across countries with different legal regimes. Therefore, it is expected that the association between market concentration and audit fees differs, depending on the country's legal regime.

Finally, we examine whether the association between audit market concentration and audit fees, as well as the effect of the country-level legal regime on the association, differs systematically between Big 4 and non-Big 4 auditors' clients. On the one hand, evidence shows that Big 4 auditors charge similar levels of fees to clients across different countries (Choi, Kim, Liu, and Simunic 
2008). This may be due to greater regulatory scrutiny and legal liability that Big 4 auditors face in different countries or situations. Therefore, cross-country differences in the effect of legal regime on the concentration-fee association, if any, would be more pronounced among the clients of nonBig 4 auditors. Conversely, Big 4 auditors may be influenced more by the legal regime or regulation changes than are non-Big 4 auditors (Ghosh and Pawlewicz 2009). Furthermore, while Big 4 auditors have a strong bargaining power that enables them to increase audit fees, non-Big 4 auditors are less likely to have such power (Ghosh and Lustgarten 2006). Consequently, the concentration-fee association and the effect of legal regime could be more pronounced among the Big 4 auditor's clients. In short, given the two conflicting predictions, it is ultimately an empirical question whether and how the two types of auditors behave differently in countries with differing legal regime strength.

With 43,914 firm-year observations collected from 17 countries from 2004 to 2015, we perform empirical analyses to test the predictions. Following prior studies, we use the countryindustry-year level Herfindahl index to measure the degree of concentration in the audit market. Our findings are summarized as follows. First, we document a significantly positive association between audit market concentration and audit fees, consistent with the concern raised by regulators. Second, we find, interestingly, that the concentration-fee association is significantly positive in countries with weak legal regimes, but weakens as the legal regime strengthens, and becomes negative as the legal regime's strength exceeds a certain level. For example, in the U.S., we observe a strong negative association, relieving the concern of U.S. regulators. Third, we find that the aforementioned concentration-fee associations are more pronounced among the clients of non-Big 4 auditors, suggesting that non-Big 4 auditors' behaviors, particularly on pricing, is influenced to a greater extent by the strength of a country's legal regime. 
Our study contributes to the literature in the following ways. First, our findings have important policy implications for regulators. Our findings clearly suggest that, contrary to the concern raised by regulators in the U.S. and the U.K., audit market concentration does not lead to higher audit fees in those countries. However, it may lead to higher fees in other countries with a weak legal regime. The findings also suggest that, in countries with strong legal regimes, the feedecreasing effect of audit market concentration induced by economies of scale dominate any potential fee-increasing effect of auditors' collusive behavior. Thus, our findings respond well to the questions raised by regulators on the effect of audit market concentation, and suggest the importance of establishing a strong legal regime or oversight mechanism that facilitates disciplining and/or scrutinizing auditors to prevent potential collusive behavior. ${ }^{6}$ In this respect, our findings also provide useful insights into the effect of auditor consolidation on audit market competition and, in turn, on audit quality and fees. ${ }^{7}$

Second, our study echoes the call by Francis et al. (2013) in encouraging further research on the effect of audit market concentration in international settings. Our findings reconcile three conflicting findings in prior studies, and thus clearly reveal the differential role of auditors in countries with different legal regimes. Our results suggest that the strength of legal regime is important in mitigating any potential negative effect of audit market concentration. Based on this study's findings, future studies of auditor behaviors should consider the effect of legal regime more carefully. For example, findings in the U.S. audit market may not be directly generalizable to audit markets in other countries with weaker legal regimes.

\footnotetext{
${ }^{6}$ Consistent with this view, the U.K. House of Lords $(2011,295)$ summarize that the concern for higher fees and lower quality has been lessened in recent years in the U.K. due to effective regulations and the corporate governance framework that give audit committee improved oversight.

${ }^{7} \mathrm{We}$, however, acknowledge that our finding that concentrated auditors do not collude at least in countries with a strong legal regime is only suggestive to audit quality. From a different view, it is also possible that lower audit fees charged by concentrated auditors in those countries may lead to inadequate audit efforts, which, in turn, result in poor audit quality (e.g., Caramanis and Lennox 2008).
} 
Finally, we add to the literature on the differential behaviors of Big 4 versus non-Big 4 auditors in an international setting. Our findings suggest that the regulators and other stakeholders, especially in countries with weak legal regimes, need to monitor the possible collusive behaviors of auditors who may take advantage of a concentrated audit market by charging excessive fees. Our findings also suggest that, in countries with strong legal regimes, regulators should focus more on the effect of concentration on audit quality, rather than audit fees. As noted earlier, empirical results on the effect of concentration on audit quality are not yet conclusive.

The rest of the paper proceeds as follows. Section 2 develops our hypotheses. Section 3 discusses the variable measurements and empirical models and Section 4 reports the sample selection procedure. Sections 5 and 6 report the results of our main analyses and sensitivity tests, respectively. The final section concludes the paper.

\section{LITERATURE REVIEW AND HYPOTHESIS DEVELOPMENT}

Since the early 1990 s, regulators in various countries has paid considerable attention to audit market concentration. For example, GAO $(2003,4)$ states that:

...the market for audit services to public companies has become increasingly concentrated - with significant barriers to entry into the market for audit services for large public companies in particular - and the largest accounting firms (domestically and globally) have increasingly had the potential to exercise significant market power....

Thus, GAO $(2003,2008)$ suggests that auditors could exercise their market power to charge very high prices. Similarly, the U.K. House of Lords $(2011,32)$ states that it is not clear "whether the fees charged by the Big Four are 'excessive' ..., however, it is logical to conclude that insufficient competition may lead to higher fees being charged." Specifically, Pong (1999) argues that higher concentration increases the chance of auditors forming a cartel or tacitly colluding to charge higher fees, aiming to increase their joint and individual profits. This view is consistent with the prediction 
from economic theory on the effect of monopoly or oligopoly: prices rise with more supplier concentration due to tacit collusion among suppliers (Weiss 1989). ${ }^{8}$ Audit clients generally agree with this view and strongly argue that regulators should intervene to lower audit fees and increase the level of competition in the audit market. ${ }^{9}$ They claim that increased audit fees since the collapse of Arthur Andersen are due to the dominant market power of the surviving Big 4 auditors (and, thus, the presumed lack of auditor competition), rather than being attributable to the more stringent legal environment and regulations enforced by SOX (Kersnar 2008). Consistent with this view, Gerakos and Syverson (2015) estimate that total audit fees would increase by between $\$ 0.47$ and $\$ 0.58$ billion per year in the U.S. audit market if the current Big 4 auditors were further reduced to Big 3, resulting in even greater concentration of the audit market. To resolve the issue, the European Commission (2011) even suggests introducing mandatory auditor rotation or joint audits. $^{10}$

However, another stream of research provides a conflicting view on the effect of audit market concentration on audit fees. Danos and Eichenseher (1982) and Pearson and Trompeter (1994) argue that the concentration of auditors in a specific industry enables them to accumulate expertise in handling industry-specific complexity during the audit. GAO (2003) also acknowledges that the growing complexity of client operations calls for auditors with greater industry-specific and technical expertise. With such expertise, auditors are able "to develop expertise-related economies of scale that allow them to maintain relatively low fees" (Pearson and Trompeter 1994, 116). Bills,

\footnotetext{
${ }^{8}$ This line of research suggests that the market concentration, combined with barriers to enter the market, leads to higher price. Both market concentration and barriers to entry are typical characteristics of the audit market (Ferguson and Scott 2013; GAO 2003).

${ }^{9}$ See, for example, the U.S. Chamber of Commerce (2006, 2007), the European Commission (2010, 2011), Oxera (2006), Kersnar (2008), and the U.K. House of Lords (2011).

${ }^{10}$ Recently, U.S. regulators did not indict two large auditors, KPMG and Ernst \& Young, criminally in cases related to the auditors' intentional wrongdoings. The concern on further increase in audit market concentration may have deterred the regulators in pursuing criminal charges (Gerakos and Syverson 2015). This anecdotal evidence suggests that U.S. regulators still worry about the potential detrimental effects of audit market concentration.
} 
Jeter, and Stein (2015), Cahan, Jeter, and Naiker (2011), Cairney and Stewart (2015), and Fung, Gul, and Krishnan (2012) also provide evidence supporting the argument that expertise allows auditors to provide their services at lower fees, at least in some industries. Similar to this view, Yardley et al. (1992) explain that the dominant auditors are able to develop efficiency gains. In GAO's (2003) survey, practicing auditors respond that concentration allows auditors to spread infrastructure costs and allocate staff and resources more efficiently. Their responses also suggest that concentration increases audit efficiency, which may lead to lower audit costs and, thus, lower audit fees. ${ }^{11}$ Based on these arguments, it is possible that auditors charge lower fees in a more concentrated market.

In summary, due to the two conflicting views, namely (i) the fee-increasing effect of collusive behavior; and (ii) the fee-decreasing effect of economies of scale, it is premature to draw any definitive conclusion on the effect of concentration on audit fees. GAO $(2003,2008)$ also expresses the difficulty of concluding whether market concentration reduces competition among auditors. Specifically, GAO (2003) explains that existing research does not conclusively identify a direct correlation between audit fees and audit market concentration or consolidation. As explained earlier, studies on the direct association between concentration and audit fees also yield mixed results, using data from three different countries, i.e., Canada, the U.S., and China, respectively (Bandyopadhyay and Kao 2004; Boone et al. 2012; Huang et al. 2016). ${ }^{12}$

\footnotetext{
${ }^{11}$ A line of economic theory, called revisionist or efficiency school, supports this argument (e.g., Bork 1978; Demsetz 1973; McGee 1988). This line of research argues that large firms can provide goods or services at lower costs due to economies of scale, leading to greater profits. As a result, the market share of such firms increases, making the market more concentrated. This view is very different from the view of general economic theory that collusion or cartel pricing leads to greater concentration and profits.

${ }^{12}$ Relatedly, GAO (2003) also investigates the effect of auditor competition and audit quality but fails to draw any clear conclusions. Therefore, GAO (2003) calls for the attention of academics to explore the issue. However, subsequent studies report conflicting findings depending on the proxies for audit quality. While Kallapur et al. (2010) and Newton et al. (2013) report that audit market concentration (as a proxy for the competition) is positively related to audit quality, Boone et al. (2012) report that concentration is negatively related to audit quality. Additionally, Francis et al. (2013) report mixed results in an international setting. They report that the dominance of Big 4 auditors
} 
Summarizing the relevant literature, Causholli, Martinis, Hay, and Knechel (2010) conclude that there is insufficient evidence on whether increased auditor mergers and concentration over time led to a detrimental effect in the audit market. Based on the aforementioned mixed views and findings, we propose and test our first research hypothesis, stated in null form:

H1: There is no association between audit market concentration and audit fees.

As the next research question, we examine how the association between audit market concentration and audit fees is affected by the strength of a country's legal regime. A strong legal regime or law enforcement promotes fair competition and prevents contracting parties from engaging in any collusive activities, such as cartel pricing (Ghosal 2011; Waked 2016). ${ }^{13}$ For example, the World Trade Organization (1998) argues that the adoption of competition law prevents excessive market concentration and the resulting structural rigidity, and thereby promotes an efficient allocation of resources. Specifically, Waked (2016) argues that strong legal enforcement of fair competition can prevent any illegal corporate behaviors intended to increase prices or fees.

Strong legal enforcement may also influence auditor behaviors (e.g., Choi and Wong 2007; Choi et al. 2008; Fan and Wong 2005; Francis et al. 2013; Francis and Wang 2008; Gul et al. 2013; Khurana and Raman 2004). With respect to audit pricing, dominant auditors may collude with other auditors to charge excessive fees in countries with weak legal regimes, while be restricted from such behavior in countries with a strong legal regime. ${ }^{14}$ Harsh penalties for tacit collusion in

over the other auditors (i.e., Big 4's market share in a country) is positively related to audit quality, while the concentration among Big 4 auditors is negatively related to audit quality. In summary, it is not clear how audit market concentration is related to both audit fees and quality.

${ }^{13}$ This law is commonly called competition law or antitrust law. The law regulates "anti-competitive conduct by companies to ensure that they do not create cartels and monopolies that would damage the interest of society." (https://en.wikipedia.org/wiki/European_Union_competition_law)

${ }^{14}$ Consistent with this view, studies find that the collusion between auditor and clients occurs in countries with a weak legal regime (Wang, Wong, and Xia 2008; Yang, Kilgore, and Hong 2001). 
countries with a strong legal regime (Waked 2016) may prevent auditors from charging excessive fees even in a highly concentrated market. In summary, the fee-increasing effect of collusive behavior is likely to be reduced in countries with a strong legal regime, while the fee-decreasing effect of economies of scale is unlikely to vary across countries with different legal regimes. Consequently, market concentration is more likely to lead to higher audit fees in countries with a weak legal regime than in countries with a strong legal regime.

Given our prediction on the effect of legal regime, we conjecture that the inconsistent prior findings on the association between audit market concentration and audit fees in different countries (Bandyopadhyay and Kao 2004; Boone et al. 2012; Huang et al. 2016) could be due to differences in the country-level legal regime. Therefore, we propose and test our second research hypothesis, stated in null form:

H2: The association between audit market concentration and audit fees in countries with a strong legal regime does not differ from that in countries with a weak legal regime.

Our final hypothesis relates to the differential behaviors of Big 4 versus non-Big 4 auditors in an international setting. There are two conflicting predictions on the difference between Big 4 and non-Big 4 auditors regarding the association between market concentration and fees. On the one hand, Big 4 auditors tend to charge similar levels of fees for similar services across different clients or countries, while non-Big 4 auditors charge significantly different levels of fees, depending on the clients or prevailing legal regime (Choi et al. 2008). In such circumstances, the audit fees for Big 4 auditors' clients should be stable across countries, regardless of the different degree of market concentration or strength of legal regime, while those for non-Big 4 auditors' clients should depend largely on audit market concentration and the legal regime of the country in which they operate. In other words, any association between audit market concentration and audit 
fees in different countries should be less pronounced among Big 4 clients than among non-Big 4 clients. $^{15}$

On the other hand, Big 4 auditors' behaviors may be more sensitive to changes in market concentration or legal regime than non-Big 4 auditors' behaviors. Ghosh and Pawlewicz (2009) report that audit fees of Big 4 auditors increased much more than those of non-Big 4 auditors after the enactment of SOX. The greater sensitivity of Big 4 auditors' behaviors to regulatory changes may arise because they face more stringent legal penalties, and have deeper pockets, in case of audit failure than non-Big 4 auditors (DeAngelo 1981), especially in countries with a strong legal regime (Choi et al. 2008). Furthermore, Big 4 auditors have stronger bargaining power than nonBig 4 auditors, enabling them to influence audit fees more substantially. Consistent with this view, Ghosh and Lustgarten (2006) report that non-Big 4 auditors face more serious price competition and, thus, face greater difficulty seeking to charge higher fees than Big 4 auditors. Therefore, from this perspective, any differential association between audit market concentration and audit fees in different countries would be more pronounced among the clients of Big 4 auditors than those of non-Big 4 auditors.

Summarizing the above arguments, we examine whether and how the two types of auditors react differently to audit market concentration in countries with different legal regimes. Given the two conflicting predictions, we propose and test our third research hypothesis, stated in null form:

H3: The association between audit market concentration and auditfees, as well as the effect of the country-level legal regime, does not differ between Big 4 and non-Big 4 clients.

\footnotetext{
${ }^{15}$ Bandyopadhyay and Kao (2004), using Canadian municipal data, report that the association between audit market concentration and audit fees is marginally significant for non-Big 4 auditors' clients, while insignificant for Big 4 auditors' clients. These findings, albeit weak, are also consistent with the view that non-Big 4 auditors are more influenced by the client or environmental characteristics than Big 4 auditors are.
} 


\section{VARIABLE MEASUREMENT AND MODEL SPECIFICATION}

\section{Measures of Audit Market Concentration}

Following prior studies, we use the Herfindahl index to gauge the degree of audit market concentration. ${ }^{16}$ We first estimate the market share of each auditor in a country-industry-year using their clients' total sales, where industries are defined by 1-digit SIC codes. We then sum the squared market share in each country-industry-year and use it as our proxy for market concentration. ${ }^{17}$ Specifically, we use two audit market concentration measures, defined as follows: $C O N C 1=\sum_{i=1}^{N}\left(\mathrm{~s}_{i} / S\right)^{2}$, where $N$ is the total number of Big 4 auditors, $S$ is the total sales of clients audited by Big 4 auditors, and $s_{i}$ is the sales of clients audited by Big 4 auditor $i$, in each country-industry-year.

CONC2 $=\sum_{i=1}^{N}\left(\mathrm{~s}_{i} / S\right)^{2}$, where $N$ is the total number of all auditors, $S$ is the total sales of clients audited by all auditors, and $s_{i}$ is the sales of clients audited by auditor $i$, in each country-industry-year;

CONC1 and CONC2 measure the audit market concentration for Big 4 auditors and all auditors, respectively. Auditor identity data are retrieved from Compustat Global and Compustat North America. To calculate reliable concentration measures, we require that at least five observations exist in a country-industry-year combination. We exclude observations that are unaudited or whose auditors are unidentified, which are the observations with auditor identification codes 0 (unaudited) or 9 (other auditor) in Compustat. We delete firms in countries with a potential miscoding of auditor identification (Francis and Wang 2008; Francis et al. 2013), such as Korea and Japan.

\footnotetext{
${ }^{16}$ Several prior studies that test the association between the Herfindhal index and audit quality interpreted the index as a proxy for auditor competition (e.g., Boone et al. 2012; Kallapur et al. 2010; Newton et al. 2013). However, it is not clear whether the index properly captures the intensity of competition (Buijink, Maijoor, and Meuwissen 1998; Dedman and Lennox 2009; Sutton 1990). Therefore, we are cautious in using the term 'competition' in this study.

17 The results using the clients' natural log of total assets are qualitatively similar. In our study, the expression 'qualitatively similar' implies that all the significant results hold so that inferences from the results remain the same.
} 


\section{Strength of legal regime}

We use two proxies for the strength of the legal regime. The first proxy, $L A W I$, is a combined index measuring the comprehensive strength of liability standards for auditors, calculated by the average of Aud_sue, Aud_san, Audev, and Enfor. Aud_sue measures investors' difficulty in recovering losses incurred by using misleading audited financial information (La Porta, Lopez-deSilanes, and Shleifer 2006). Aud_san captures the strength of criminal sanctions imposable on auditors when audited financial statements omit material information (La Porta et al. 2006). Audev captures the quality of public company auditors' working environment, incorporating factors related to auditor licensing, training programs, quality assurance programs, the auditor rotation system, and sanctions and litigation against auditors (Brown, Preiato, and Tarca 2014). Enfor captures the degree of enforcement activity by independent enforcement bodies, including the governments' responsibilities and activities for monitoring and promoting compliance with accounting and auditing standards, and the extent of resources devoted to enforcement reviews of financial statements (Brown et al. 2014). ${ }^{18} L A W I$ suits the purpose of our study because it directly measures auditors' legal liability and the strength of legal enforcement related to external audits.

The second proxy, $L A W 2$, captures the strength of the overall legal environment, and has been widely used in prior accounting/auditing studies (Choi and Wong 2007; DeFond and Hung 2004, 2007; Francis and Wang 2008; Francis et al. 2013; Leuz, Nanda, and Wysocki 2003). Specifically, LAW2 is calculated by the average value of Anti_dir, Eff_jud, and Disclosure. Anti_dir is a combined score of anti-director rights (La Porta, Lopez-de-Silanes, Shleifer, and

\footnotetext{
${ }^{18}$ Since Brown et al. (2014) provide the indices for 2002, 2005, and 2008, we match each observation with the scores of the closest year. For example, observations in the years 2004, 2005, and 2006 are matched with the scores of 2005. Observations in the years on or after 2007 are matched with the scores of 2008.
} 
Vishny 1998). Eff_jud assesses the efficiency and integrity of the legal environment related to business (La Porta et al. 1998). Finally, Disclosure assesses a country's disclosure requirements to protect investors (La Porta et al. 2006). The components comprising LAW1 and LAW2 are converted into values between 0 and 1 , and then averaged to form comprehensive measures of the strength of legal regime. ${ }^{19}$ Detailed definitions of all variables are provided in the Appendix.

\section{Empirical Model}

To examine the association between the audit market concentration and audit fees as hypothesized in H1, we estimate the following model:

$$
\begin{aligned}
& F E E_{i t}=b_{0}+b_{1} C O N C_{j k t}+b_{2} L A W_{k t}+b_{3} B I G 4_{i t}+b_{4} S I Z E_{i t}+b_{5} L E V_{i t} \\
& +b_{6} R O A_{i t}+b_{7} I_{N V R E C_{i t}}+b_{8} L_{O S S}+b_{9} L^{2 N T A C C R} R_{i t}+b_{10} M B_{i t} \\
& +b_{11}{I F R S_{i t}}+b_{12} F S R_{i t}+b_{13} N B S_{i t}+b_{14} N G S_{i t}+b_{15} L G D P_{k t} \\
& +b_{16} L M K T_{k t}+\text { industry/year indicators }+ \text { error }_{i t}
\end{aligned}
$$

where, for firm $i$, industry $j$, country $k$, and year $t, F E E$ is the natural logarithm of audit fees (in thousands of U.S. dollars); CONC (i.e., CONC1 or CONC2) is the audit market concentration measure in a country-industry-year; $L A W$ (i.e., $L A W 1$ or $L A W 2$ ) is the strength of the legal regime. For $\mathrm{H} 1$, we examine whether the coefficient on $C O N C$ (i.e., $b_{1}$ ) differs from 0 . If $b_{1}$ is positive (negative), this means that the auditors charge higher (lower) fees as the audit market becomes more concentrated. Based on the findings of Choi et al. (2008) that audit fees increase monotonically with the strength of a country's legal regime, we expect the coefficient on $L A W$ (i.e., $b_{2}$ ) to be positive.

\footnotetext{
${ }^{19}$ When we measure the strength of the legal regime with the rule of law index assessed by the World Justice Project (WJP), the results are qualitatively similar. Since WJP has published the rule of law index since 2012, we apply the score on 2012 for the years before 2012. We also test several other proxies for the strength of legal regime used in prior studies. The (untabulated) empirical results are qualitatively similar in most analyses.
} 
Additionally, we include several client-specific control variables known to affect audit fees (e.g., Abbott, Parker, and Peters 2006; Carcello, Hermanson, Neal, and Riley 2002; Choi et al. 2008; Ghosh and Lustgarten 2006; Hackenbrack and Knechel 1997; Kim, Liu, and Zheng 2012; Menon and Williams 2001; Simunic 1980; Stice 1991). BIG4 is an indicator variable that equals 1 if the firm is audited by a Big 4 auditor, and 0 otherwise. SIZE is the natural logarithm of total assets. $L E V$ is the ratio of total liabilities to total assets. $R O A$ is net income divided by total assets. INVREC is the sum of inventory and receivables divided by total assets. LOSS is an indicator variable for reported losses. LNTACCR is the natural logarithm of the absolute value of total accruals, where total accruals are defined as net income minus operating cash flows. $M B$ is the ratio of market value of equity to book value of equity. IFRS is an indicator variable that equals 1 if a firm's financial statements are prepared in accordance with the International Financial Reporting Standards (IFRS) for the year, and 0 otherwise. FSR is the portion of foreign sales to total sales; NBS is the natural logarithm of 1 plus the number of business segments; and NGS is the natural logarithm of 1 plus the number of geographic segments. These variables capture firm size, profitability, and complexity, which are known determinants of audit fees.

We also include macroeconomic variables to control for unobservable factors that may affect the level of audit fees across countries (Choi et al. 2008; Francis et al. 2013). LGDP is the natural logarithm of GDP per capital in U.S. dollars for each country-year. LMKT is the natural logarithm of a country's stock market capitalization in billions of U.S. dollars for each year. Finally, we include year and industry fixed effects to control for their potential influences on audit fees. Detailed definitions of all variables are provided in the Appendix.

To test our second hypothesis, regarding the influence of a country's legal regime strength on the audit market concentration-fee association, we estimate the following model: 


$$
\begin{aligned}
& F E E_{i t}=b_{0}+b_{1} C O N C_{j k t}+b_{2} L A W_{k t}+b_{3} C O N C_{j k t} * L A W_{k}+b_{4} B I G 4_{i t}
\end{aligned}
$$

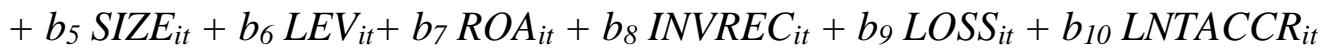

$$
\begin{aligned}
& +b_{11} M B_{i t}+b_{12} I F R S_{i t}+b_{13} F_{S R} R_{i t}+b_{14} N B S_{i t}+b_{15} N G S_{i t} \\
& +b_{16} L G D P_{k t}+b_{17} L M K T_{k t}+\text { industry/year indicators }+ \text { error }_{i t}
\end{aligned}
$$

where all variables are defined analogous to those in Eq. (1). The coefficient on the interaction term between $C O N C$ and $L A W\left(\right.$ i.e., $b_{3}$ ) represents the effect of legal regime on the association between audit market concentration and audit fees. If $b_{1}$ is positive (negative) and $b_{3}$ is negative, this means that the positive (negative) association between audit market concentration and audit fees is less (more) pronounced in countries with a strong legal regime.

To examine our final hypothesis, $\mathrm{H} 3$, we divide the sample into two subgroups: (i) clients audited by a Big 4 auditor; and (ii) those audited by a non-Big 4 auditor. We then separately estimate Eq. (2) for each subgroup and compare the coefficients on CONC and CONC*LAW between the two subgroups.

\section{SAMPLE SELECTION AND DESCRIPTIVE STATISTICS}

\section{Sample Selection Procedures}

Our initial sample comprises all nonfinancial firms in Compustat Global and Compustat North America from 2004 to 2015. The collapse of Arthur Andersen caused auditors worldwide to adjust their client portfolios in 2002 and 2003, resulting in a significant number of auditor changes (DeFond and Lennox 2011; Landsman, Nelson, and Rountree 2009). Our sample period starts from 2004 to avoid the potential influence of such dramatic auditor changes. ${ }^{20}$

\footnotetext{
${ }^{20}$ Prior studies note that there exists auditor identity miscoding problem in Compustat Global from 2005 (e.g., Francis and Wang 2008; Francis et al. 2013). While it is not clear how the problem influences our empirical results, we argue that the problem causes measurement error in our audit market concentration (CONC) and Big 4 indicator (BIG4) variables, potentially making it more difficult to reject the null hypotheses. It is practically impossible for us to use
} 
From the initial sample of 371,041 firm-year observations, firms in countries without necessary data to measure legal regime strength are deleted, leaving 298,103 firm-year observations from 41 countries. These 41 countries are those included in Brown et al. (2014) and La Porta et al. (1998, 2006). We further require observations to have audit fee data in Worldscope, which reduces the sample to 138,644 observations across 36 countries. We also exclude observations without necessary information to construct the control variables, reducing the sample size to 78,824 observations from 36 countries. We further require at least five observations in a country-industry-year combination to measure audit market concentration at the industry level. We also exclude countries with fewer than 100 observations. The final sample consists of 43,914 observations from 17 countries. We winsorize all continuous variables at the top and bottom 1 percent to mitigate the effect of outliers.

\section{Descriptive Statistics}

Table 1 presents the country-by-country descriptive statistics for our main test variables as well as country-level control variables. The number of observations presented in Column (1) varies across countries. For example, of the 43,914 observations in our final sample, U.S. data accounts for the largest portion, at approximately 61.8 percent. The portion of observations from other countries ranges from 0.4 percent (Belgium) to 8.8 percent (Australia). We address the issue of unbalanced distribution across countries in the sensitivity analyses.

Column (2) shows the mean value of audit fees presented in the natural logarithm of thousands of U.S. dollars (FEE). The sample average of FEE is 6.028, which is equivalent to

the data for the period before 2001 (before the collapse of Arthur Andersen), because audit fee data are not much available at that time. For example, in year 2000 (the last year before the collapse of Arthur Andersen), we find that there exist only 264 observations that meet our sample selection criteria. 
US\$ 414,828 . The mean value of FEE in each country is distributed from 4.239 (Malaysia) to 7.116 (U.S.). Columns (3) and (4) display the mean of the two audit market concentration measures, CONC1 and $C O N C 2$, respectively. The sample averages of the two measures are similar, i.e., 0.447 for $C O N C 1$ and 0.429 for $C O N C 2$. The standard deviations of the average CONC1 and CONC2 across countries are 0.085 and 0.086 (untabulated), respectively, suggesting that our measures of audit market concentration vary significantly across the 17 countries. The U.S. has the lowest audit market concentration (i.e., 0.307 for $C O N C 1$ and 0.295 for $C O N C 2$ ), while India has the highest concentration (i.e., 0.667 for $C O N C 1$ and 0.656 for $C O N C 2$ ). The proxies for legal regime strength, presented in Columns (5) and (6), also show high variations across countries. LAWI ranges from a minimum value of 0.523 (Germany) to a maximum value of 0.979 (Canada). LAW2 shows a similar pattern. ${ }^{21}$

The average values of the time-variant country-level macro variables, $L G D P$ and $L M K T$, are 10.266 and 6.966, respectively, as shown in the bottom of Columns (7) and (8). The average percentage of firms audited by one of the Big 4 auditors (BIG4), as presented in Column (9), is 90.2 percent. The relatively high average percentage of firms audited by the Big 4 is partly attributable to deleting observations with unidentified auditors (i.e., those with auditor code "9" in Compustat) when calculating the concentration measure. These deleted observations were generally classified as clients of non-Big 4 auditors in prior studies. We also delete observations in industries with a small number of firms (fewer than five), many of which are audited by nonBig 4 auditors, further contributing to the large percentage of Big 4-audited firms.

\section{[Insert Table 1 about here]}

\footnotetext{
21 The Pearson (Spearman) correlation between LAW1 and LAW2 is 0.795 (0.737), suggesting that the two variables represent a similar construct.
} 
Table 2 summarizes the descriptive statistics for all firm-level and country-level variables. We skip detailed explanations for these variables because they are self-explanatory and we do not observe any unusual distributional characteristics. ${ }^{22}$

\section{[Insert Table 2 about here]}

\section{EMPIRICAL FINDINGS}

\section{Analyses of $\mathrm{H} 1$ and $\mathrm{H} 2$}

Table 3 reports the results of regressions in Eq. (1) and (2). Columns (1) to (4) present the results of regressions in Eq. (1) to test H1. In Columns (1) and (2) [Columns (3) and (4)], we use CONC1 [CONC2] as the proxy for audit market concentration. In Columns (1) and (3) [Columns (2) and (4)], we use $L A W 1$ [LAW2] to measure the strength of a country's legal regime. The reported t-statistics (in parentheses) in Table 3 and subsequent tables are based on standard errors clustered by firm.

In Section A, we provide the estimated coefficients on the test variables. In Columns (1) to (4), the coefficients on $C O N C$ are all positive and statistically significant. For example, in Column (1), when we use CONCl and $L A W 1$, the coefficient on CONCl is 0.293 and significant at less than the 1 percent level $(t$-value $=4.71)$. These results suggest that as the audit market becomes more concentrated in a given country-industry-year, auditors tend to charge higher fees. ${ }^{23}$ This corroborates the concerns of audit clients who strongly advocate regulatory intervention to lower

\footnotetext{
${ }^{22}$ Although not tabulated for simplicity, we check the correlation among variables used in our analyses. We note that our country-level control variables are highly correlated with CONC1 (CONC2) and $L A W$. Furthermore, we notice that the correlations between SIZE and ROA, between SIZE and LNTACCR, and between ROA and LOSS are greater than 0.4 . We perform several additional analyses and fail to find any evidence that multicollinearity causes serious problems in our analyses.

${ }^{23}$ The finding is also economically significant. The standard deviation of CONC1 is 0.117 (reported in Table 2). One standard deviation increase of $C O N C l$ from the mean value $(0.356)$ increases audit fees by $0.034(=0.293 \times 0.117)$, which indicates an 0.56 percent increase in the natural logarithm of audit fees compared to the sample mean of 6.028 in Table 1 (equivalent to $\$ 14,349$ ).
} 
audit fees and increase the level of competition in the audit market. Meanwhile, the coefficients on $L A W$ are all significantly positive in Columns (1) to (4). For example, in Column (1), the coefficient on $L A W l$ is 1.307 and highly significant at less than the 1 percent level $(t$-value $=11.45)$. This is consistent with Choi et al.'s (2008) finding that the strength of a country's legal regime is positively related to the level of audit fees.

In Sections B and C, we provide the coefficients of firm-specific and country-level control variables, respectively. All the coefficients on the control variables are consistent throughout Columns (1) to (4). Specifically, Big 4 auditors (BIG4) charge higher audit fees, and firms that are large (SIZE), highly levered (LEV), less profitable (ROA, LOSS), and more complex (INVREC, LNTACCR, MB, FSR, NBS, NGS) bear higher audit fees. These results are consistent with prior studies' findings that audit pricing is an increasing function of the client's size, risk, and complexity of business operations (Abbott et al. 2006; Carcello et al. 2002; Hackenbrack and Knechel 1997; Simunic 1980; Stice 1991). In addition, the positive coefficient on IFRS indicates that auditors charge higher fees when auditing financial statements prepared in accordance with IFRS, consistent with Kim et al.'s (2012) findings. In Section C, both LGDP and LMKT have significantly positive coefficients, indicating that country-level macroeconomic factors influence audit pricing (Choi et al. 2008). We note that the explanatory powers of regressions in Columns (1) to (4), as reflected in the adjusted $\mathrm{R}^{2}$, are very high (exceeding 80 percent), suggesting that our audit fee model is well specified.

In Columns (5) to (8), we present the results of regressions in Eq. (2) to test H2. We estimate Eq. (2) to test $\mathrm{H} 2$ regarding the impact of legal regime strength on the association between audit market concentration and audit fees. The layout of Columns (5) to (8) is identical to that of Columns (1) to (4). In all four columns, the coefficients on CONC and $L A W$ remain significantly 
positive, consistent with those in Columns (1) to (4). More importantly, we find that the coefficients on the interaction term between $C O N C$ and $L A W$ are all negative and significant at less than the 1 percent level. For example, in Column (5), the coefficient on CONC1*LAW1 is 2.452 and significant at the 1 percent level $(t$-value $=-4.20)$. The results documented in Column (5) indicate that the effect of audit market concentration on audit fees is about -0.385 (the sum of coefficients on $C O N C 1$ and $C O N C 1 * L A W 1)$ if $L A W 1$ is equal to 1 . The sum of the two coefficients is significantly different from $0(F$-value $=5.27, p$-value $=0.0217)$. Similarly, in Column $(6)$, the effect of audit market concentration on audit fees is about -0.857 if $L A W 2$ is equal to 1 , which is significantly different from $0(F$-value $=9.62, p$-value $=0.0019)$. These results suggest that a strong legal regime completely negates the audit fees increase related to audit market concentration, and is even associated with a decrease in audit fees as the market becomes more concentrated. ${ }^{24}$

The above results clearly show why several prior studies yield mixed findings on the concentration-fee association, i.e., the difference in a country's legal regime seems to be the moderating factor. Huang et al. (2016) use data from China, a country characterized by a very weak legal regime (not used in our study), whereas Bandyopadhyay and Kao (2004) use data from Canada where the legal regime is strong. When we restrict the sample to U.S. firms and repeat the analyses, we find that the effect of audit market concentration on audit fees is significantly negative, consistent with the findings of Boone et al. (2012). Specifically, when we perform the analyses with Eq. (1) and U.S. data only (without the $L A W$ variable), the coefficient on CONC1 is -0.542

\footnotetext{
${ }^{24}$ The finding is also economically significant. If we set $L A W 1$ as 0.523 (Germany), the net effect of audit market concentration on audit fees is $0.785(=2.067-2.452 \times 0.523)$ when we use the results documented in Column (5). Given that the mean value of $C O N C 1$ in Germany is 0.478 , it implies that the net effect of audit market concentration on audit fees is $0.375(=0.785 \times 0.478)$. However, when we set the value of $L A W 1$ as 0.729 (Switzerland, close to the mean value of $L A W 1$ ), the net effect is 0.133 . The effect further decreases and even becomes negative when $L A W 1$ is 0.979 (Canada), where the net effect is -0.145 . The net effect in Germany is translated into about 6 percent increase of audit fees (equivalent to $\$ 34,707$ ), based on the mean value of the natural logarithm of audit fees, while it is a 2 percent decrease in Canada (equivalent to $-\$ 18,081$ ). These differences clearly suggest that strength of legal regime greatly affects the association between audit market concentration and audit fees.
} 
$(t$-value $=-2.24)$. When we use U.K. (Australian) [Canadian] data only, the coefficient is -0.413 (0.016) [-0.524] and statistically insignificant.

In summary, the results documented in Columns (5) to (8) of Table 3 do not support regulators and audit clients' concerns that auditors exploit oligopolistic power in a concentrated audit market to charge excessive fees, at least in the U.S. and other countries with a strong legal regime. In the presence of such a regime, the fee-decreasing effect of economies of scale may prevail over the fee-increasing effect of cartel pricing. Without such strong legal enforcement mechanisms, dominant auditors in a concentrated market could charge excessive fees by using their oligopolistic power.

In Sections B and C, all the coefficients for the control variables presented in Columns (5) to (8) are similar to those in Columns (1) to (4). We, therefore, do not repeat detailed explanations of the estimated coefficients on firm-specific and country-level control variables.

\section{[Insert Table 3 about here]}

For ease of understanding, our results for $\mathrm{H} 1$ and $\mathrm{H} 2$ are illustrated graphically in Figure 1. Panel A of Figure 1 shows that audit fees are positively associated with audit market concentration in general (H1). In Panel B, we illustrate the association separately for two subgroups with different strengths in the country-level legal regime $(\mathrm{H} 2)$. The concentration-fee association remains positive in countries with a weak legal regime. In sharp contrast, the positive association weakens and even becomes negative under a strong legal regime. The absolute value of the slope is larger (that is, the slope is steeper) in countries with a weak legal regime than in those with a strong legal regime; hence, we observe a positive slope when we combine all observations, as in Panel A.

\section{[Insert Figure 1 about here]}




\section{Analyses of $\mathbf{H 3}$}

Table 4 reports the results of estimating Eq. (2) separately for the subsamples of Big 4 and non-Big 4 clients. By doing so, we are able to test whether auditor type affects the concentrationfee association, and also the influence of the country-level legal regime on the association. ${ }^{25}$ The results for the Big 4 [non-Big 4] subsample is presented in Columns (1), (3), (5), and (7) [Columns (2), (4), (6), and (8)]. In Columns (1) to (4) [Columns (5) to (8)], we use CONC1 [CONC2] as the proxy for audit market concentration. In Columns (1), (2), (5), and (6) [Columns (3), (4), (7), and (8)], we measure legal regime strength using LAW1 [LAW2].

For the Big 4 subsample in Column (1), all three test variables, $C O N C, L A W$, and $C O N C * L A W$, have statistically significant coefficients, consistent with the results in Table 3 . For example, the coefficients on CONC1, LAW1, and CONC1 *LAW1 are $1.698(t$-value $=3.81), 2.279$ $(t$-value $=7.80)$, and -1.988 $(t$-value $=-3.31)$, respectively. For the non-Big 4 subsample in Column (2), the results are similar, but the magnitudes of the coefficients are much larger than those in Column (1). For example, the coefficients on CONC1, LAWI, and CONC1*LAW1 are 5.241 ( $t$ value $=4.56), 3.045(t$-value $=3.86)$, and $-6.411(t$-value $=-4.08)$, respectively. Section D of Table 4 presents the $C h i^{2}$ statistics for testing the difference in the coefficients between the two subsamples. These statistics reveal that the coefficient on $C O N C 1$ of the non-Big 4 subsample is significantly greater than that of the Big 4 subsample at less than the 1 percent level $\left(C h i^{2}\right.$ statistics $=8.39)$. Similarly, the coefficient on $C O N C 1 * L A W 1$ for the non-Big 4 subsample is significantly larger in magnitude than that for the Big 4 subsample at less than the 1 percent level

\footnotetext{
${ }^{25}$ Note that we omit BIG4 variable from Eq. (2). Further, we do not tabulate the results using Eq. (1) in Table 4 because the results can be directly inferred from those of Eq. (2).
} 
$\left(C h i^{2}\right.$-statistics $\left.=7.00\right) .{ }^{26} \mathrm{We}$ find, however, that the coefficients on LAWI are not statistically different between the two subsamples. Collectively, the results indicate that the concentration-fee association is much greater for non-Big 4 auditors than for Big 4 auditors. The results also suggest that a strict legal regime attenuates the positive association between audit market concentration and audit fees for non-Big 4 auditors, to a greater extent, than for the Big 4 auditors. The results in other columns are all qualitatively similar to those tabulated in Columns (1) and (2). ${ }^{27}$

Overall, we find that our results for testing $\mathrm{H} 1$ and $\mathrm{H} 2$ are more pronounced for non-Big 4 client firms than for Big 4 client firms. The results in Table 4 are consistent with the view that Big 4 auditors' fees are less likely to be affected by audit market concentration than those of non-Big 4 auditors, as Big 4 auditors tend to charge similar fee levels across different clients, countries, or situations (Choi et al. 2008). These results also support the view that non-Big 4 auditors are inclined to change their behaviors, particularly on pricing, depending on the clients' characteristics and the strength of the prevailing legal environment (Choi et al. 2008). ${ }^{28}$

For brevity, we do not repeat our explanations of the estimated coefficients on control variables. The estimated results are qualitatively similar to those tabulated in Table 3.

\footnotetext{
${ }^{26}$ We again estimate the economic significance of our findings. For Big 4 auditors in Germany where the value of $L A W 1$ is 0.523 , the net effect of audit market concentration on audit fees is 0.658 when we use the results documented in Column (1). Given that the mean value of CONCl in Germany is 0.478 , it implies that the net effect on audit fees is $0.315(=0.658 \times 0.478)$. For non-Big 4 auditors in Germany, the net effect is 0.909 . Based on the mean value of the natural logarithm of audit fees for Big 4 and non-Big 4 auditors in Germany, these net effects are translated into approximately 5 percent and 16 percent increase of audit fees for German Big 4 and non-Big 4 auditors, respectively (equivalent to $\$ 32,551$ and $\$ 41,454$, respectively). When we apply the same logic to Big 4 and non-Big 4 auditors in Canada where the value of $L A W 1$ is 0.979 , the net effects are about 2 percent and 7 percent decrease in audit fees for Big 4 and non-Big 4 auditors, respectively (equivalent to $-\$ 13,723$ and $-\$ 33,499$, respectively).

${ }^{27}$ As reported in Table 1, our sample predominantly consists of Big 4 auditors' clients. Despite the small sample size, we have a more pronounced results within the non-Big 4 subsample suggesting that the documented findings likely persist among small firms audited by the non-Big 4.

${ }^{28}$ Our findings are not consistent with the finding of Ghosh and Pawlewicz (2009) who document a significantly greater fee increase after the enactment of SOX for the clients of Big 4 auditors than those of non-Big 4 auditors. One possible reason for Ghosh and Pawlewicz's (2009) finding is that the legal liability for the Big 4, due to SOX, might increase more dramatically than that for the non-Big 4 . As a result, audit fee increased more for Big 4 auditors' clients. In contrast, our study assumes that the country-level legal regime applies uniformly to both Big 4 and non-Big 4 auditors. If this is not the case, our findings should be interpreted with caution.
} 


\section{[Insert Table 4 about here]}

To corroborate the results on the differences between Big 4 and non-Big 4 auditors, we perform an additional analysis to see whether the Big 4 audit fee premium differs, depending on audit market concentration and strength of the legal regime. If non-Big 4 auditors charge higher audit fees in a concentrated audit market in countries with a weak legal regime, but Big 4 auditors are less likely to do so, then the Big 4 audit fee premium should decrease with the extent of audit market concentration in countries with a weak legal regime. Consistent with our expectations, in countries with a weak legal regime, we find that the Big 4 premium significantly decreases as the audit market becomes more concentrated (untabulated). However, we do not find such evidence in countries with a strong legal regime. The finding suggests that, in countries with a weak legal regime, non-Big 4 auditors tend to charge a similar level of audit fees to the fees charged by Big 4 auditors in a concentrated audit market, while they are less likely to do so in a non-concentrated audit market. The above results lend further support to our findings documented in Table 4 .

\section{SENSITIVITY AND ADDITIONAL ANALYSES}

\section{Additional Analyses to Control for the Differences in Country-level Sample Size}

As reported in Table 1, the sample is dominated by a few countries and, thus, these countries may heavily influence our regression results. We adopt the following three approaches to check whether the difference in sample size per country affects our results.

First, we re-estimate Eqs. (1) and (2) using a weighted least squares (WLS) regression assigning an equal weight to each country. This method should resolve any distortion caused by over-representation of a few countries (Solon, Haider, and Wooldridge 2015). The results are 
reported in Column (1) of Table $5 .{ }^{29}$ Column (1-1) [(1-2)] of Panel A presents the results for testing H1 [H2], while Column (1-1) [(1-2)] of Panel B presents the results for Big 4 [non-Big 4] subsample analysis to test H3. For brevity, we only tabulate the coefficients of the main test variables in Table 5. The results in Column (1) of both panels are qualitatively similar to those reported in Tables 3 and 4.

Second, we repeat the analyses after dropping U.S. observations, which account for the largest portion of our total sample. The results are qualitatively similar to those reported previously (untabulated).

Third, we exclude countries with fewer than 1,000 observations and re-estimate the models. On applying this condition, many countries with a weak legal regime are removed from the sample. Although the signs and magnitudes all remain consistent with those reported previously, we fail to reject the null hypothesis of $\mathrm{H} 3$. Overall, the results of these additional analyses mitigate the concern that our main findings are driven by a few countrties with large sample size.

\section{[Insert Table 5 about here]}

\section{Alternative Measures of the Test Variables}

We use alternative measures of the key variables of our interest to check the robustness of our findings. We have already reported several test results related to this issue in relevant parts of our study. Additionally, we perform the following analyses. First, we employ two alternative concentration proxies using a residual approach, following Francis et al. (2013): They use the country-level collective market share of the Big 4 auditors as their main proxy for market concentration, supplementing their results using the residual from a regression of the Big 4's collective market share on the set of country-level variables. By using the residual approach, the

\footnotetext{
${ }^{29}$ Note that we report the results using LAWI and CONCl in Table 5 for the simplicity. The results using other measures are qualitatively similar to those tabulated.
} 
authors control for the high correlation between country-level variables and their main concentration proxy. Following Francis et al. (2013), we regress the country-level market share of Big 4 auditors on a set of country-level variables (i.e., $L A W, L G D P$, and $L M K T$ ), and use the residuals as an alternative proxy for audit market concentration. In addition, we also use the residuals from regressing our audit market concentration measures (CONC1 and CONC2) on the set of country-level variables. Both analyses yield results consistent with our main findings (untabulated).

Second, we recalculate our concentration measure in a country-year combination without considering the industry. ${ }^{30}$ We perform these analyses because the auditors' pricing power or oligopolistic dominance could be determined at the country level rather than at the industry level, especially in countries with a relatively small sample size. If an industry has only a few firms, dominance within that industry may not play a significant role. Therefore, we check whether country-year-level audit market concentration, rather than country-industry-year-level concentration, play a more important role in determining audit fees. ${ }^{31}$ The results, which are tabulated in Column (2) of Table 5, are all qualitatively similar to those previously tabulated. Importantly, the estimated coefficients in Column (2) of Table 5 are generally larger in absolute magnitude and more significant than the corresponding coefficients observed in Tables 3 and 4.

Third, we recalculate our concentration measure based on the 2-digit SIC industry code. We originally use the 1-digit industry code to avoid inordinate loss in the sample size when calculating

\footnotetext{
${ }^{30}$ For this test, we require at least 100 observations in a country-year combination. The results using cut-off values of 75 or 125 does not qualitatively change our results. We choose 100 as a cut-off value because the choice yields a sample size $(\mathrm{N}=42,117)$ similar to that of the main tests $(\mathrm{N}=43,914)$.

${ }^{31}$ In our main analyses, we select firms with the minimum sample size per country-industry-year of 5 . We also perform sensitivity analyses by changing the cut-off value to 6,8 , or 10 observations in a country-industry-year. The empirical results are qualitatively similar when we set the cut-off value to 6 . However, when we set the cut-off value to 8 or 10 , the difference in the coefficients between Big 4 and non-Big 4 subgroups becomes insignificant although the signs are in the expected directions. One possible reason for the weaker results is the weak statistical power caused by the smaller sample size of the non-Big 4 subsamples.
} 
concentration measures. Nevertheless, when we tighten the industry definition, although the sample size is reduced by 11 percent, our results do not materially change. As reported in Column (3) of Table 5, all the results are consistent with those reported previously. The only distinction exists when testing $\mathrm{H} 3$, where we fail to find a significant difference between the Big 4 and nonBig4 auditors' clients, as reported in Column (3) of Section B in Panel B, Table 5. The difference, however, becomes marginally significant when we use CONC2 rather than CONC1 (untabulated). These findings suggest that our results are insensitive to different industry classifications.

\section{Other Analyses}

There may be potential endogeneity with respect to auditor selection. To address this issue, we perform a propensity score matching (PSM) analysis (Lawrence, Minutti-Meza, and Zhang 2011). Specifically, we first estimate the probability that a firm selects a Big 4 auditor. ${ }^{32}$ We then match a non-Big 4 client with a Big 4 client with the closest predicted value from the first stage regression, within a maximum distance of 5 percent. We successfully match 6,926 clients of Big 4 auditors with the same number of non-Big 4 clients. The empirical results using the PSM sample are reported in Column (4) of Table 5. Although the sample size is significantly reduced, the results do not change qualitatively. Applying a maximum distance of 1 percent also does not qualitatively alter the results.

As explained earlier, regulators have great concerns over the potential effect of the audit market concentration on both audit fees and audit quality. It is possible that audit fees and audit

\footnotetext{
${ }^{32}$ We use the following model to predict Big 4 auditor choice following Chaney, Jeter, and Shivakumar (2004) and Lawrence et al. (2011):

Big4 $=\alpha_{0}+\alpha_{1} S I Z E+\alpha_{2} A T U R N+\alpha_{3} Q U I C K+\alpha_{4} L E V+\alpha_{5} R O A+I n d u s t r y / y e a r$ indicators + error, where $A T U R N$ is sales divided by total assets; $Q U I C K$ is current assets minus inventory divided by current liabilities. Other variables are defined analogous to those used in Eqs. (1) and (2).
} 
quality are simultaneously determined. For example, based on the fees, auditors may decide how much audit efforts they should exert to a specific client. We, thus, re-estimate the regressions by explicitly controlling for audit quality. Specifically, we replace our control variable LNTACCR (natural logarithm of the absolute value of total accruals) with the absolute magnitude of discretionary accruals adjust for firm performance measured by return on assets (Kothari, Leone, and Wasley 2005) and reexamine our previous findings. Untabluated results show that though the coefficients on absolute discretionary accruals is positive and significant, our main results do not change qualitatively.

\section{CONCLUSION}

While the dominance of a few large auditors in the audit market has received considerable attention from regulators and academics, only a few studies have examined this issue, providing, at best, mixed evidence. Our study provides strong and reliable evidence on the positive impact of audit market concentration on audit fees using international data from 17 countries around the world. We further show that this impact differs systematically between Big 4 and non-Big 4 auditors across different countries with differing levels of legal regime strength. In this respect, our findings provide regulators and many other interested parties with valuable insights into the effect of audit market structure on auditor behaviors, particularly audit pricing.

However, our study is subject to several limitations and, thus, should be interpreted cautiously. First, we focus on the overall country-level market structure, rather than the office- or city-level structure. This approach has both pros and cons. Since a few large audit offices dominate the entire country-level audit market in most countries, except for a few large countries such as the U.S (Francis et al. 2013), we believe that investigating the country-level market structure is 
meaningful for drawing general conclusions in most countries. Nevertheless, we are not able to consider any potential differences at the local office level. We hope that future studies further examine the effect of concentration among local offices at the city level.

Second, as in other studies, we use the Herfindahl index to measure the degree of concentration in each country-industry-year level. Regulators are concerned with the potential negative effects of audit market concentration on competition. However, it is not clear whether the Herfindahl index properly captures the degree of competition among auditors (Dedman and Lennox 2009). We hope future studies will clarify the link between concentration and competition. Though our results suggest that audit market concentration potentially reduces competition (and thus leads to excessive audit pricing) in countries with a weak legal regime, the association between audit market concentration and competition is not yet clear, especially in countries with a strong legal regime.

Third, unlike the studies that investigate the effect of auditor mergers, there may be endogeneity with respect to the audit market concentration measure. It is, thus, possible that some unidentified factors simultaneously influence both audit market concentration and audit fees. Fourth, our findings do not address whether clients pay an appropriate level of audit fees. Thus, the expression "excessive fees," used in this study to describe the documented association in countries with a weak legal regime, may be inaccurate and thus be interpreted cautiously. Finally, our results do not specifically address whether there is an appropriate level of audit market concentration. We believe such issues deserve additional investigation in future research. 


\section{REFERENCES}

Abbott, L. J., S. Parker, and G. F. Peters. 2006. Earnings management, litigation risk, and asymmetric audit fee responses. Auditing: A Journal of Practice \& Theory 25 (1): 85-98.

Abidin, S., V. Beattie, and A. Goodacre. 2010. Audit market structure, fees and choice in a period of structural change: Evidence from the UK - 1993-2003. British Accounting Review 2 (3): 187-206.

Bandyopadhyay, S., and J. L. Kao. 2004. Market structure and audit fees: A local analysis. Contemporary Accounting Research 21 (3): 529-561.

Bigus, J., and R.-C. Zimmermann. 2008. Non-audit fees, market leaders and concentration in the German audit market: A descriptive analysis. International Journal of Auditing 12 (3): 159179.

Bills, K., D. Jeter, and S. Stein. 2015. Auditor industry specialization and evidence of cost efficiencies in homogenous industries. The Accounting Review 90 (5): 1721-1754.

Boone, J. P., I. K. Khurana, and K. K. Raman. 2012. Audit market concentration and auditor tolerance for earnings management. Contemporary Accounting Research 29 (4): 1171-1203.

Bork, R. 1978. Antitrust Paradox. New York: Free Press.

Brown, P., J. Preiato, and A. Tarca. 2014. Measuring country differences in enforcement of accounting standards: An audit and enforcement proxy. Journal of Business, Finance, and Accounting 41 (1/2): 1-52.

Buijink, W., S. Maijoor, and R. Meuwissen. 1998. Competition in auditing: Evidence from entry, exit, and market share mobility in Germany versus the Netherlands. Contemporary Accounting Research 15 (3): 385-404.

Cahan, S., D. Jeter, and V. Naiker. 2011. Are all industry specialist auditors equal? Auditing: A Journal of Practice \& Theory 30 (4): 191-222.

Cairney, T., and E. Stewart. 2015. Audit fees and client industry homogeneity. Auditing: A Journal of Practice \& Theory 34 (4): 33-57.

Caramanis, C., and C. Lennox. 2008. Audit effort and earnings management. Journal of Accounting and Economics 45 (1): 116-138.

Carcello, D., R. Hermanson, T. L. Neal, and R. R. Riley. 2002. Board characteristics and audit fees. Contemporary Accounting Research 19 (3): 365-385. 
Causholli, M., M. Martinis, D. Hay, and W. Knechel. 2010. Audit markets, fees and production: Towards an integrated view of empirical audit research. Journal of Accounting Literature 30: $167-215$.

Chaney, P. K., D. C. Jeter, and L. Shivakumar. 2004. Self-selection of auditors and audit pricing in private firms. The Accounting Review 79 (1): 51-72.

Choi, J.-H., S. Choi, C. E. Hogan, and J. Lee. 2013. The effect of human resource investment in internal control on the disclosure of internal control weakness. Auditing: A Journal of Practice \& Theory 32 (4): 169-199.

Choi, J.-H., J.-B. Kim, X. Liu, and D. Simunic. 2008. Audit pricing, legal liability regimes, and Big 4 premiums: Theory and cross-country evidence. Contemporary Accounting Research 25 (1): 1-49.

Choi, J.-H., S. Kim, and K. K. Raman. 2016. Did the 1998 merger of Price Waterhouse and Coopers \& Lybrand increase audit quality? Contemporary Accounting Research (forthcoming).

Choi, J.-H., and T. J. Wong. 2007. Auditors' governance functions and legal environments: An international investigation. Contemporary Accounting Research 24 (1): 13-46.

Christiansen, M., and A. Loft. 1992. Big players and small players: A study of increasing concentration in the Danish market for auditing services. European Accounting Review 1 (2): 277-301.

Danos, P., and J. W. Eichenseher. 1982. Auditor industry dynamics: Factors affecting changes in client-industry market shares. Journal of Accounting Research 20 (2): 604-616.

DeAngelo, L. E. 1981. Auditor size and audit quality. Journal of Accounting and Economics 3 (3): 183-199.

Dedman, E., and C. Lennox. 2009. Perceived competition, profitability and the withholding of information about sales and the cost of sales. Journal of Accounting and Economics 48 (2/3): 210-230.

DeFond, M., and M. Hung. 2004. Investor protection and corporate governance: Evidence from worldwide CEO turnover. Journal of Accounting Research 42 (2): 269-312.

DeFond, M., and M. Hung. 2007. Investor protection and analysts' cash flow forecasts around the world. Review of Accounting Studies 12 (2/3): 377-419.

DeFond, M., and C. Lennox. 2011. The effect of SOX on small auditor exits and audit quality. Journal of Accounting and Economics 52 (1): 21-40. 
Demsetz, H. 1973. Industry structure, market rivalry and public policy. Journal of Law and Economics 16 (1): 1-19.

European Commission. 2010. Audit Policy: Lessons from the Crisis. Green Paper. Brussels.

European Commission. 2011. Proposal for a Regulation of the European Parliament and of the Council on specific requirements regarding statutory audit of public-interest entities. Brussels.

Feldman, E. 2006. A basic quantification of competitive implication of the demise of Arthur Andersen. Review of Industrial Organization 29 (3): 193-212.

Fan, J., and T. J. Wong. 2005. Do external auditors perform a corporate governance role in emerging markets? Evidence from East Asia. Journal of Accounting Research 43 (1): 35-72.

Ferguson, A., and T. Scott. 2013. What if there were three? Audit pricing within the Big 4 and the PricewaterhouseCoopers' premium in the Australian audit market. International Journal of Auditing 18 (1): 57-67.

Francis, J. R., P. N. Michas, and S. Seavey. 2013. Does audit market concentration harm the quality of audited earnings? Evidence from audit market in 42 countries. Contemporary Accounting Research 30 (1): 322-355.

Francis, J., and D. Wang. 2008. The joint effect of investor protection and Big 4 audits on earnings quality around the world. Contemporary Accounting Research 25 (1): 157-191.

Fung, S., F. Gul, and J. Krishnan. 2012. City-level auditor industry specialization, economies of scale, and audit pricing. The Accounting Review 87 (4): 1281-1307.

General Accounting Office (GAO). 2003. Public Accounting Firms: Mandated Study on Consolidation and Competition. Washington, D.C.

Gerakos, J., and C. Syverson. 2015. Competition in the audit market: Policy implications. Journal of Accounting Research 53 (4): 725-775.

Ghosal, V. 2011. The law and economics of enhancing cartel enforcement: Using information from non-cartel investigations to prosecute cartels. Review of Law and Economics 7 (2): 501-538.

Ghosh, A., and S. Lustgarten. 2006. Pricing of initial audit engagements by large and small audit firms. Contemporary Accounting Research 23 (2): 333-368.

Ghosh, A., and R. Pawlewicz. 2009. The impact of regulation on auditor fees: Evidence from the Sarbanes-Oxley Act. Auditing: A Journal of Practice \& Theory 28 (2): 171-197.

Gilling, D. M., and P. J. Stanton. 1978. Changes in the structure of the auditing profession in Australia. Abacus 14 (1): 66-80. 
Government Accountability Office (GAO). 2008. Public Accounting Firms: Continued Concentration in Audit Market for Large Public Companies Does Not Call for Immediate Action. Washington, D.C.

Gul, F. A., G. Zhou, and X. Zhu. 2013. Investor protection, firm informational problems, Big N auditors, and cost of debt around the world. Auditing: A Journal of Practice \& Theory 32 (3): $1-30$.

Hackenbrack, K., and W. R. Knechel. 1997. Resource allocation decisions in audit engagements. Contemporary Accounting Research 14 (3): 481-500.

Huang, T., H. Chang, and J. Chiou. 2016. Audit market concentration, audit fees, and audit quality: Evidence from China. Auditing: A Journal of Practice \& Theory 35 (2): 121-145.

Ivancevich, S. H., and A. Zardkoohi. 2000. An exploratory analysis of the 1989 accounting firm megamergers. Accounting Horizons 14 (4): 389-401.

Johnson, E. N., K. B. Walker, and E. Westergaard. 1995. Supplier concentration and pricing of audit services in New Zealand. Auditing: A Journal of Practice \& Theory 14 (2): 74-89.

Kersnar, J. 2008. Mending fences. CFO. Available at: http://cfo.com/article.cfm/10768242/1/c_10792674? f=search.

Kallapur, S., S. Sankaraguruswamy, and Y. Zang. 2010. Audit market concentration and audit quality. Working paper. Indian School of Business.

Kim, J.-B., X. Liu, and L. Zheng. 2012. The impact of mandatory IFRS adoption on audit fees: Theory and Evidence. The Accounting Review 87 (6): 2061-2094.

Khurana, I., and K. K. Raman. 2004. Litigation risk and the financial reporting credibility of Big 4 versus non-Big 4 audits: Evidence from Anglo-American countries. The Accounting Review 79 (2): 473-495.

Kothari, S., A. Leone, and C. Wasley. 2005. Performance matched discretionary accrual measures. Journal of Accounting and Economics 39 (1): 163-197.

Landsman, W., K. Nelson, and B. Rountree. 2009. Auditor switches in the pre- and post-Enron eras: Risk or realignment? The Accounting Review 84 (2): 531-558.

La Porta, R., F. Lopez-de-Silanes, and A. Shleifer. 2006. What works in securities laws? Journal of Finance 61 (1): 1-32.

La Porta, R., F. Lopez-de-Silanes, A. Shleifer, and R. Vishny. 1998. Law and finance. Journal of Political Economy 106 (6): 1113-1155. 
Lawrence, A., M. Minutti-Meza, and P. Zhang. 2011. Can Big 4 versus non-Big 4 differences in audit-quality proxies be attributed to client characteristics? The Accounting Review 86 (1): 259-286.

Leuz, C., D. Nanda, and P. Wysocki. 2003. Earnings management and investor protection: An international comparison. Journal of Financial Economics 69 (3): 505-527.

McGee, J. 1988. Industrial Organization. Englewood Cliffs, N. J., Prentice Hall.

Menon, K., and D. D. Williams. 2001. Long-term trends in audit fees. Auditing: A Journal of Practice \& Theory 20 (1): 115-136.

Moizer, P., and S. Turley. 1989. Changes in the UK market for audit services: 1972-1982. Journal of Business, Finance, and Accounting 16 (1): 41-53.

Newton, N. J., D. Wang, M. S. Wilkins. 2013. Does a lack of choice lead to lower quality? Evidence from auditor competition and client restatements. Auditing: A Journal of Practice \& Theory 32 (3): 31-67.

Numan, W., and M. Willekens. 2012. An empirical test of spatial competition in the audit market. Journal of Accounting and Economics 53 (1/2): 450-465.

Oxera. 2006. Competition and choice in the U.K. audit market: Prepared for the Department of Trade and Industry and Financial Reporting Council. Oxera Consulting. Available at http://www.oxera.com/Latest-Thinking/Publications/Reports/2006/Competition-and-choicein-the-UK-audit-market.aspx.

Pearson, T., and G. Trompeter. 1994. Competition in the market for audit services: The effect of supplier concentration on audit fees. Contemporary Accounting Research 11 (1): 115-135.

Pong, C. 1999. Auditor concentration: A replication and extension for the UK audit market 19911995. Journal of Business, Finance, and Accounting 26 (3/4): 451-475.

Pong, C., and S. Burnett. 2006. The implications of merger for market share, audit pricing and non-audit fee income: The case of PricewaterhouseCoopers. Managerial Auditing Journal 21 (1): 7-22.

Simunic, D. A. 1980. The pricing of audit services: Theory and evidence. Journal of Accounting Research 22 (3): 161-190.

Solon, G., S. J. Haider, and J. M. Wooldridge. 2015. What are we weighting for? The Journal of Human Resources 50 (2): 301-316.

Stice, J. D. 1991. Using financial and market information to identify pre-engagement factors associated with lawsuits against auditors. The Accounting Review 66 (3): 516-533. 
Sullivan, M. 2002. The effect of the Big 8 accounting firm mergers on the market for audit services. Journal of Law and Economics 45 (2): 375-399.

Sutton, J. 1990. Sunk Costs and Market Structure: Price Competition, Advertising and the Evolution of Concentration. MIT Press, Cambridge, MA.

U.K. House of Lords. 2011. Auditors: Market Concentration and Their Role, Volume II: Evidence. The Stationery Office Limited, London.

U.S. Chamber of Commerce. 2006. Auditing: A Profession at Risk. Washington, D.C.

U.S. Chamber of Commerce. 2007. Commission on the Regulation of the U.S. Capital Markets in the $21^{\text {st }}$ Century. Washington, D.C.

U.S. Treasury. 2006. Remarks by Treasury Secretary Henry M. Paulson. Available at https://www.treasury.gov/press-center/press-releases/Pages/hp174.aspx.

Wang, Q., T. J. Wong, and L. Xia. 2008. State ownership, institutional environment and auditor choice: Evidence from China. Journal of Accounting and Economics 46 (1): 112-134.

Waked, D. 2016. Adoption of antitrust laws in developing countries: Reasons and challenges. Journal of Law, Economics \& Policy 12 (2): 193-230.

Weiss, L. 1989. Concentration and Price. MIT Press. Cambridge, MA.

World Trade Organization. 1998. Synthesis on the Relationship of Trade and Competition Policy to Development and Economic Growth. Available at https://docsonline.wto.org/dol2fe/Pages/FormerScriptedSearch/directdoc.aspx?DDFDocume nts/t/WT/WGTCP/W80.DOC.

Yang, L., Q. Tang, A. Kilgore, and J. Y. Hong. 2001. Auditor-government associations and auditor independence in China. The British Accounting Review 33 (2): 175-189.

Yardley, J., N. Kauffman, T. Cairney, and W. Albrecht. 1992. Supplier behavior in the U. S. audit market. Journal of Accounting Literature 2: 151-184. 


Variable Definition Data Source

Dependent variables

FEE Natural logarithm of audit fees in thousands of U.S. dollars. Worldscope

Test variables

\begin{tabular}{|c|c|c|}
\hline CONC1 & $\begin{array}{l}\text { Audit market Herfindahl index calculated based on the sales } \\
\text { of an auditor's clients in the same country-industry-year } \\
\text { combination; }\end{array}$ & $\begin{array}{l}\text { Compustat } \\
\text { Global }\end{array}$ \\
\hline CONC2 & $\begin{array}{l}\text { Audit market Herfindahl index calculated based on the sales } \\
\text { of a Big } 4 \text { auditor's clients in the same country-industry-year } \\
\text { combination; }\end{array}$ & $\begin{array}{l}\text { Compustat } \\
\text { Global }\end{array}$ \\
\hline Aud_sue & $\begin{array}{l}\text { An index of the procedural difficulty in recovering losses } \\
\text { from the auditors in a civil liability case arising from using } \\
\text { misleading information in the audited financial statements } \\
\text { accompanying the prospectus; }\end{array}$ & $\begin{array}{l}\text { La Porta et al. } \\
\text { (2006) }\end{array}$ \\
\hline Aud_san & $\begin{array}{l}\text { An index of criminal sanctions applicable to the auditor (or } \\
\text { its officers) when the financial statements accompanying the } \\
\text { prospectus omit material information; }\end{array}$ & $\begin{array}{l}\text { La Porta et al. } \\
\text { (2006) }\end{array}$ \\
\hline Audev & $\begin{array}{l}\text { An index capturing the quality of the public company } \\
\text { auditors' working environment; }\end{array}$ & $\begin{array}{l}\text { Brown et al. } \\
(2014)\end{array}$ \\
\hline Enfor & $\begin{array}{l}\text { An index capturing the degree of enforcement activity by } \\
\text { independent enforcement bodies; }\end{array}$ & $\begin{array}{l}\text { Brown et al. } \\
(2014)\end{array}$ \\
\hline Anti_dir & An index of anti-director rights; & $\begin{array}{l}\text { La Porta et al. } \\
\text { (1998) }\end{array}$ \\
\hline Eff_jud & $\begin{array}{l}\text { An assessment of the efficiency and integrity of the legal } \\
\text { environment affecting business, particularly foreign firms; }\end{array}$ & $\begin{array}{l}\text { La Porta et al. } \\
\text { (1998) }\end{array}$ \\
\hline Disclosure & An index of disclosure requirements; & $\begin{array}{l}\text { La Porta et al. } \\
\text { (2006) }\end{array}$ \\
\hline$L A W 1$ & $\begin{array}{l}\text { The average of } A u d \_s u e, A u d \_s a n, A u d e v \text { and Enfor } \\
\text { capturing the comprehensive strength of country-level legal } \\
\text { regime that is related to the external audits. Each component } \\
\text { is converted into values between } 0 \text { and } 1 \text { before being } \\
\text { averaged; }\end{array}$ & $\begin{array}{l}\text { La Porta et al. } \\
\text { (2006), Brown } \\
\text { et al. (2014) }\end{array}$ \\
\hline$L A W 2$ & $\begin{array}{l}\text { The average value of Anit_dir, Eff_jud, and Disclosure } \\
\text { capturing the strength of country-level legal regime based on } \\
\text { the legal liability of investor protection. Each component is } \\
\text { converted into values between } 0 \text { and } 1 \text { before being } \\
\text { averaged. }\end{array}$ & $\begin{array}{l}\text { La Porta et al. } \\
(1998,2006)\end{array}$ \\
\hline
\end{tabular}

Firm-specific control variables

BIG4 Indicator variable equal to 1 if the auditor is one of the Big 4, Compustat 0 otherwise;

SIZE Natural logarithm of total assets;

Compustat

LEV Total liabilities divided by total assets;

Compustat

ROA Net income divided by total assets;

Compustat 
INVREC Inventory plus receivables, divided by total assets;

Compustat

LOSS Indicator variable equal to 1 for observations with negative

Compustat net income, 0 otherwise;

LNTACCR Natural logarithm of absolute value of total accruals; Compustat

$M B \quad$ Market-to-book ratio;

Compustat

IFRS Indicator variable equal to 1 for the firm-year in which

Worldscope

financial statements are prepared in accordance with the IFRS, 0 otherwise;

FSR The portion of foreign sales to total sales; $\quad$ Worldscope

NBS Natural logarithm of 1 plus the number of business segments; Worldscope

NGS Natural logarithm of 1 plus the number of geographic Worldscope

ATURN Sales divided by total assets; Compustat

QUICK Current assets less inventories, divided by current liabilities. Compustat

Country-level control variables

LGDP Natural logarithm of gross domestic products per capita; World

Economic

Outlook

LMKT Natural logarithm of stock market capitalization for the year World Bank (in billions of U.S. dollars).

This table presents the definitions and measurements of the variables used in the main analyses. 


\section{Figure 1. The Association Between the Audit Market Concentration and Audit Fees}

\section{Panel A: The General Association Between Audit Market Concentration and Audit Fees}



\section{Panel B: The Association Between Audit Market Concentration and Audit Fees Depending on the Strength of Legal Regime}

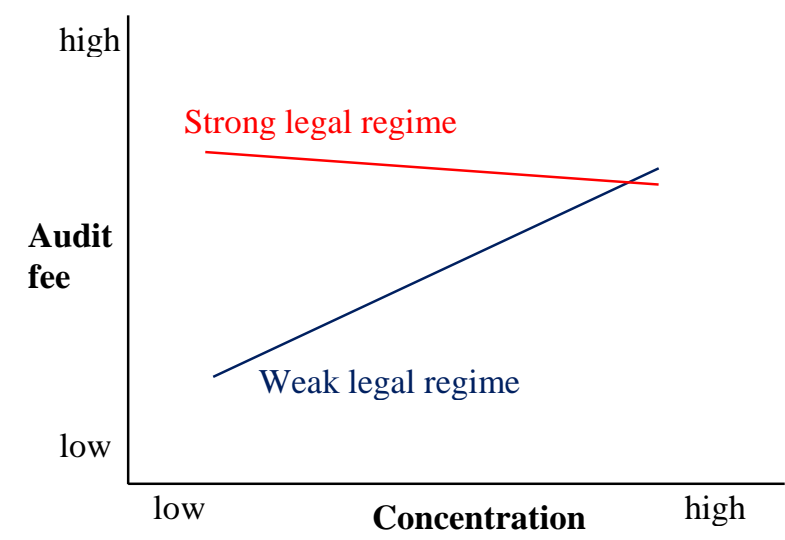

Panel A shows the association between audit market concentration and audit fees in general. As audit market concentration increases, audit fee increases indicating a positive association between the two variables. Panel B shows the association between the two variables depending on the strength of country-level legal regime. In weak legal regime countries, there exists a positive association between the two variables, as observed in Panel A. However, the positive association weakens as the legal regime becomes more stringent and eventually becomes negative as the legal regime strength exceeds a certain level. It implies that audit fees decrease with audit market concentration in countries with a very strong legal regime. The absolute value of the slope is greater for countries with a weak legal regime than that for countries with a strong legal regime as seen in Panel B. Therefore, in the general sample combining both groups of countries, we observe a positive association as reported in Panel A. 
Table 1. Descriptive Statistics for Dependent, Test and Macroeconomic Variables by Country

\begin{tabular}{|c|c|c|c|c|c|c|c|c|c|}
\hline Country & $\begin{array}{c}(1) \\
\text { Sample } \\
\text { Size }\end{array}$ & $\begin{array}{c}(2) \\
F E E\end{array}$ & $\begin{array}{c}\text { (3) } \\
\text { CONC1 }\end{array}$ & $\begin{array}{c}\text { (4) } \\
\text { CONC2 }\end{array}$ & $\begin{array}{c}(5) \\
L A W 1\end{array}$ & $\begin{array}{c}\text { (6) } \\
L A W 2\end{array}$ & $\begin{array}{c}(7) \\
L G D P\end{array}$ & $\begin{array}{c}\text { (8) } \\
L M K T\end{array}$ & $\begin{array}{c}\text { (9) } \\
\text { BIG4 }\end{array}$ \\
\hline Australia & 3,850 & 5.173 & 0.447 & 0.411 & 0.754 & 0.625 & 10.758 & 6.954 & 0.758 \\
\hline Belgium & 166 & 6.428 & 0.375 & 0.365 & 0.816 & 0.331 & 10.729 & 5.694 & 0.867 \\
\hline Canada & 1,526 & 6.735 & 0.434 & 0.425 & 0.979 & 0.672 & 10.716 & 7.465 & 0.965 \\
\hline France & 768 & 6.917 & 0.468 & 0.445 & 0.603 & 0.492 & 10.670 & 7.567 & 0.910 \\
\hline Germany & 946 & 6.381 & 0.478 & 0.458 & 0.523 & 0.381 & 10.684 & 7.320 & 0.865 \\
\hline Hong Kong & 508 & 6.239 & 0.533 & 0.503 & 0.848 & 0.697 & 10.368 & 7.654 & 0.929 \\
\hline India & 524 & 4.532 & 0.667 & 0.656 & 0.593 & 0.631 & 7.266 & 7.065 & 0.996 \\
\hline Italy & 219 & 6.331 & 0.465 & 0.450 & 0.616 & 0.314 & 10.486 & 6.342 & 0.900 \\
\hline Malaysia & 2,465 & 4.239 & 0.390 & 0.342 & 0.735 & 0.597 & 8.990 & 5.731 & 0.839 \\
\hline Norway & 379 & 6.124 & 0.478 & 0.472 & 0.839 & 0.619 & 11.441 & 5.549 & 0.937 \\
\hline Singapore & 1,316 & 4.911 & 0.424 & 0.409 & 0.696 & 0.633 & 10.635 & 6.148 & 0.930 \\
\hline South Africa & 600 & 6.679 & 0.472 & 0.439 & 0.543 & 0.561 & 8.780 & 6.565 & 0.902 \\
\hline Spain & 267 & 6.776 & 0.508 & 0.501 & 0.660 & 0.492 & 10.321 & 7.069 & 0.970 \\
\hline Switzerland & 459 & 6.891 & 0.475 & 0.467 & 0.729 & 0.489 & 11.224 & 7.113 & 0.976 \\
\hline Taiwan & 683 & 4.741 & 0.321 & 0.306 & 0.576 & 0.450 & 9.994 & 6.456 & 0.958 \\
\hline United Kingdom & 2,090 & 6.261 & 0.365 & 0.352 & 0.769 & 0.694 & 10.676 & 7.930 & 0.806 \\
\hline \multirow[t]{2}{*}{ U.S. } & 27,148 & 7.116 & 0.307 & 0.295 & 0.865 & 0.700 & 10.781 & 9.796 & 0.819 \\
\hline & 43,914 & 6.028 & 0.447 & 0.429 & 0.714 & 0.552 & 10.266 & 6.966 & 0.902 \\
\hline
\end{tabular}

This table presents country-by-country descriptive statistics for the dependent and main test variables, as well as the macroeconomic country-level variables. Column (1) presents the sample size per country. Column (2) presents the mean values of the natural logarithm of audit fees (FEE) by country. Columns (3) and (4) present the mean values of the audit market concentration measures (CONC1 and CONC2) by country. Columns (5) and (6) present the country-level mean values of $L A W 1$ and the values of $L A W 2$, respectively. Columns (7) and (8) present the mean values of the macroeconomic factors, natural logarithm of GDP per capita $(L G D P)$ and natural logarithm of stock market capitalization (LMKT), respectively. Column (9) shows the mean portion of firms whose auditor is one of the Big 4 auditors $(B I G 4)$. In the bottom line, the sum of the statistics is presented in Column (1) and the averages of the country-level means are presented in Columns (2) to (9). See the Appendix for detailed variable definitions. 
Table 2. Descriptive Statistics for All Variables

\begin{tabular}{|c|c|c|c|c|c|c|c|}
\hline Variables & Mean & SD & P10 & $\mathbf{P 2 5}$ & Median & P75 & P90 \\
\hline$F E E$ & 6.541 & 1.556 & 4.407 & 5.537 & 6.664 & 7.577 & 8.454 \\
\hline CONC1 & 0.356 & 0.117 & 0.270 & 0.291 & 0.315 & 0.365 & 0.496 \\
\hline CONC2 & 0.339 & 0.110 & 0.254 & 0.273 & 0.305 & 0.335 & 0.465 \\
\hline BIG4 & 0.836 & 0.370 & 0.000 & 1.000 & 1.000 & 1.000 & 1.000 \\
\hline$S I Z E$ & 5.982 & 2.079 & 3.339 & 4.527 & 5.928 & 7.407 & 8.739 \\
\hline$L E V$ & 0.494 & 0.282 & 0.158 & 0.294 & 0.479 & 0.646 & 0.803 \\
\hline$R O A$ & -0.041 & 0.277 & -0.271 & -0.037 & 0.031 & 0.075 & 0.125 \\
\hline INVREC & 0.246 & 0.189 & 0.027 & 0.086 & 0.213 & 0.367 & 0.515 \\
\hline LOSS & 0.332 & 0.471 & 0.000 & 0.000 & 0.000 & 1.000 & 1.000 \\
\hline$L N T A C C R$ & 3.065 & 2.182 & 0.258 & 1.586 & 3.074 & 4.551 & 5.898 \\
\hline MB & 2.703 & 4.299 & 0.530 & 1.027 & 1.821 & 3.215 & 5.805 \\
\hline IFRS & 0.200 & 0.400 & 0.000 & 0.000 & 0.000 & 0.000 & 1.000 \\
\hline$F S R$ & 0.238 & 0.307 & 0.000 & 0.000 & 0.056 & 0.439 & 0.748 \\
\hline$N B S$ & 1.127 & 0.453 & 0.693 & 0.693 & 1.099 & 1.609 & 1.792 \\
\hline$N G S$ & 1.146 & 0.489 & 0.693 & 0.693 & 1.099 & 1.609 & 1.792 \\
\hline$L G D P$ & 10.582 & 0.619 & 10.218 & 10.642 & 10.756 & 10.814 & 10.903 \\
\hline$L M K T$ & 8.680 & 1.511 & 6.456 & 7.282 & 9.658 & 9.835 & 10.087 \\
\hline
\end{tabular}

This table presents descriptive statistics for all variables used in this paper. See the Appendix for detailed variable definitions. 
Table 3. The Association Between Audit Market Concentration, Legal Regime, and Audit Fees

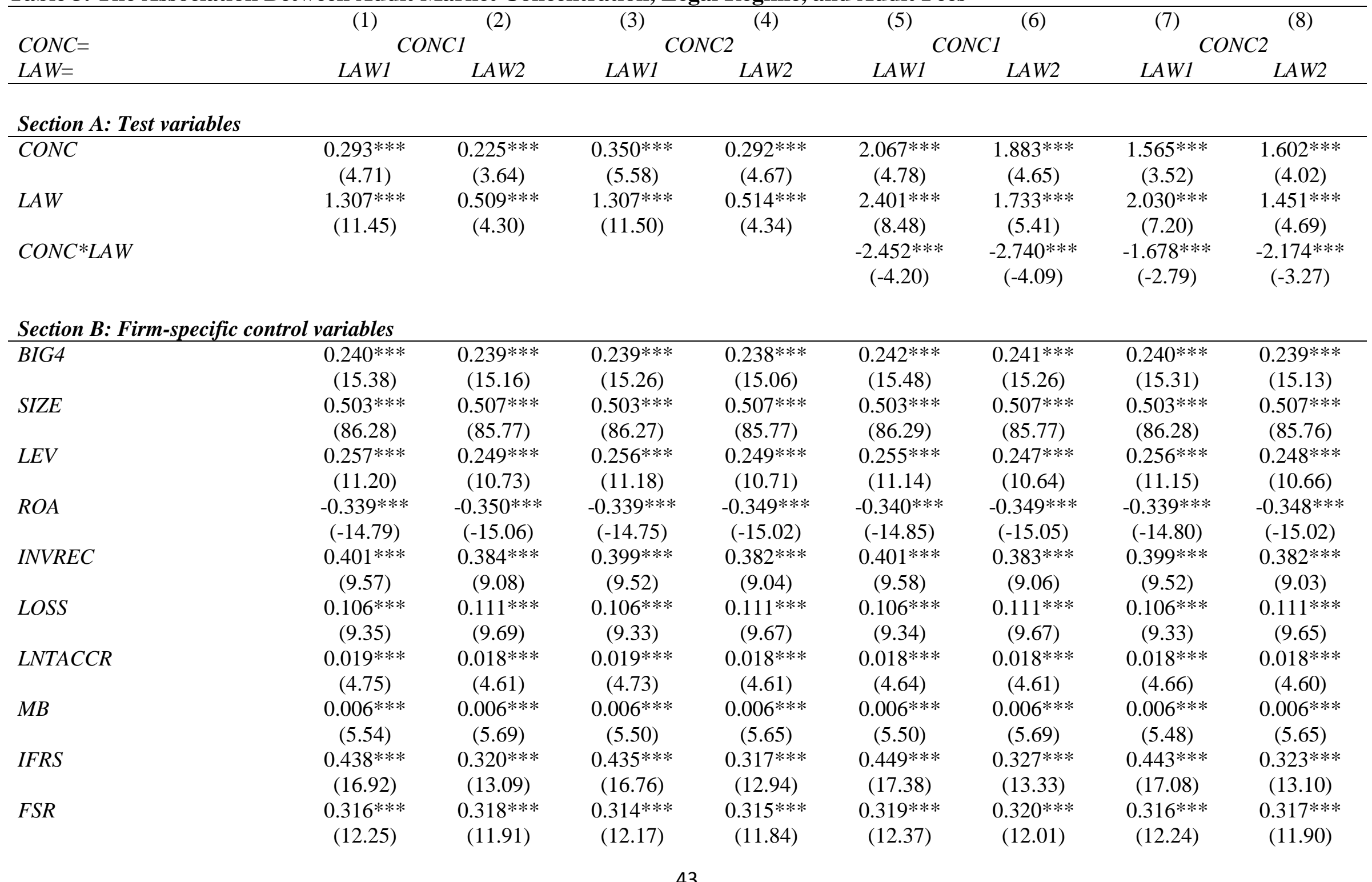




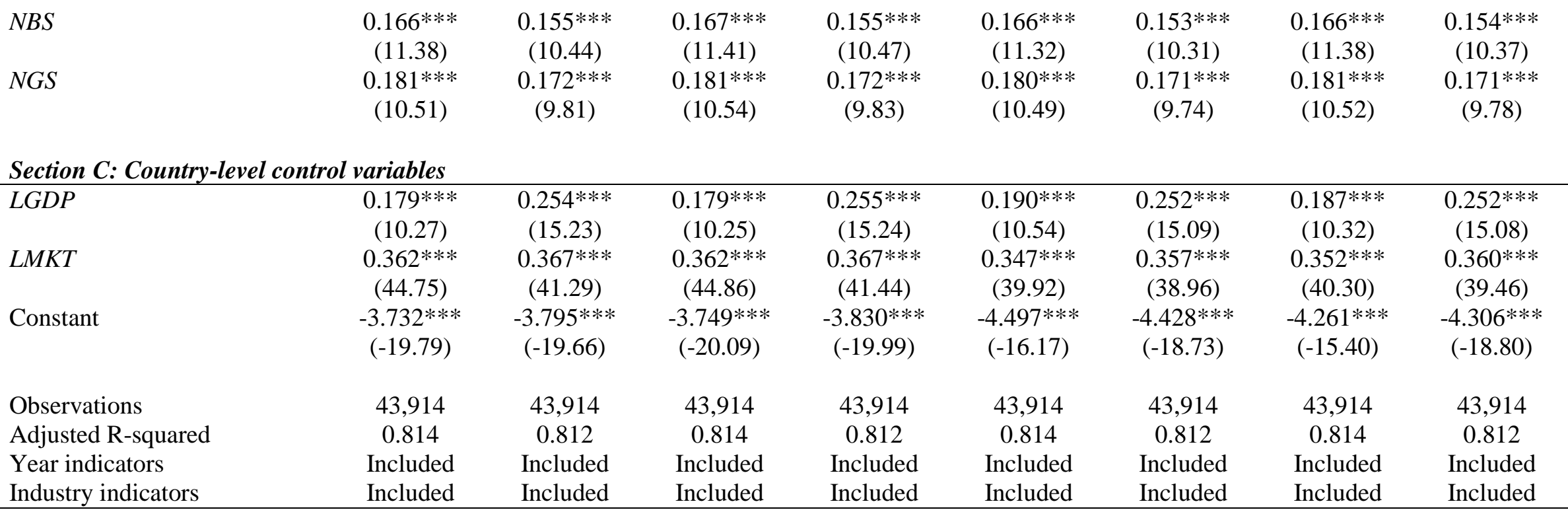

This table presents the regression results to test H1 using Eq. (1) in Columns (1) to (4) and the regression results to examine H2 using Eq. (2) in Columns (5) to (8). In Columns (1), (2), (5) and (6), we measure audit market concentration with CONC1 whereas we use CONC2 in Columns (3), (4), (7) and (8). In columns with odd numbers, we measure the strength of legal regime with $L A W 1$. In columns with even numbers, we measure the strength of legal regime with $L A W 2$. See the Appendix for detailed variable definitions. The numbers in parentheses represent $t$-statistics based on standard errors clustered by firm. $* * *, * *$, and $*$ indicate statistical significance at the $1 \%, 5 \%$, and $10 \%$ levels, respectively. 
Table 4. The Association Between Audit Market Concentration, Legal Regime, and Audit Fees: Big 4 Versus Non-Big 4 Auditors

\begin{tabular}{|c|c|c|c|c|c|c|c|c|}
\hline \multirow{4}{*}{$\begin{array}{l}C O N C= \\
L A W= \\
\text { Auditors }\end{array}$} & (1) & (2) & (3) & (4) & (5) & (6) & (7) & (8) \\
\hline & \multicolumn{4}{|c|}{ CONCl } & \multirow{2}{*}{\multicolumn{4}{|c|}{ CONC2 }} \\
\hline & \multicolumn{2}{|c|}{$L A W 1$} & \multicolumn{2}{|c|}{$L A W 2$} & $L A W 1$ & & & $L A W 2$ \\
\hline & Big4 & Non-Big4 & Big4 & Non-Big4 & Big4 & Non-Big4 & Big4 & Non-Big4 \\
\hline \multicolumn{9}{|c|}{ Section A: Test variables } \\
\hline CONC & $\begin{array}{c}1.698 * * * \\
(3.81)\end{array}$ & $\begin{array}{c}5.241 * * * \\
(4.56)\end{array}$ & $\begin{array}{c}1.462^{* * * *} \\
(3.56)\end{array}$ & $\begin{array}{c}5.379 * * * \\
(3.93)\end{array}$ & $\begin{array}{c}1.349 * * * \\
(2.95)\end{array}$ & $\begin{array}{c}4.250 * * * \\
(3.33)\end{array}$ & $\begin{array}{c}1.308 * * * \\
(3.17)\end{array}$ & $\begin{array}{c}4.347 * * * \\
(3.43)\end{array}$ \\
\hline$L A W$ & $\begin{array}{c}2.279 * * * \\
(7.80)\end{array}$ & $\begin{array}{c}3.045^{* * * *} \\
(3.86)\end{array}$ & $\begin{array}{c}1.612 * * * \\
(4.81)\end{array}$ & $\begin{array}{c}2.971 * * * \\
(3.13)\end{array}$ & $\begin{array}{c}2.007 * * * \\
(6.87)\end{array}$ & $\begin{array}{c}2.244 * * * \\
(2.82)\end{array}$ & $\begin{array}{c}1.430 * * * \\
(4.36)\end{array}$ & $\begin{array}{c}2.091 * * \\
(2.41)\end{array}$ \\
\hline$C O N C * L A W$ & $\begin{array}{c}-1.988^{* * * *} \\
(-3.31)\end{array}$ & $\begin{array}{c}-6.411 * * * \\
(-4.08)\end{array}$ & $\begin{array}{c}-2.092^{* * * *} \\
(-3.06)\end{array}$ & $\begin{array}{c}-7.952^{* * * *} \\
(-3.57)\end{array}$ & $\begin{array}{c}-1.426^{* * *} \\
(-2.30)\end{array}$ & $\begin{array}{c}-4.976 * * * \\
(-2.86)\end{array}$ & $\begin{array}{c}-1.734 * * \\
(-2.51)\end{array}$ & $\begin{array}{c}-6.247 * * * \\
(-2.99)\end{array}$ \\
\hline \multicolumn{9}{|c|}{ Section B: Firm-specific control variables } \\
\hline SIZE & $\begin{array}{c}0.508 * * * \\
(77.73)\end{array}$ & $\begin{array}{c}0.473^{* * * *} \\
(37.69)\end{array}$ & $\begin{array}{c}0.513 * * * \\
(77.48)\end{array}$ & $\begin{array}{c}0.471 * * * \\
(37.78)\end{array}$ & $\begin{array}{c}0.507 * * * \\
(77.72)\end{array}$ & $\begin{array}{c}0.474 * * * \\
(37.65)\end{array}$ & $\begin{array}{c}0.513 * * * \\
(77.47)\end{array}$ & $\begin{array}{c}0.472 * * * \\
(37.67)\end{array}$ \\
\hline$L E V$ & $\begin{array}{c}0.267 * * * \\
(9.69)\end{array}$ & $\begin{array}{c}0.219^{* * * *} \\
(6.06)\end{array}$ & $\begin{array}{c}0.257 * * * \\
(9.17)\end{array}$ & $\begin{array}{c}0.215^{* * *} \\
(5.92)\end{array}$ & $\begin{array}{c}0.267 * * * \\
(9.70)\end{array}$ & $\begin{array}{c}0.219 * * * \\
(6.05)\end{array}$ & $\begin{array}{c}0.257 * * * \\
(9.18)\end{array}$ & $\begin{array}{c}0.214^{* * * *} \\
(5.91)\end{array}$ \\
\hline$R O A$ & $\begin{array}{c}-0.392 * * * \\
(-13.98)\end{array}$ & $\begin{array}{c}-0.246 * * * \\
(-6.65)\end{array}$ & $\begin{array}{c}-0.405 * * * \\
(-14.17)\end{array}$ & $\begin{array}{c}-0.245^{* * * *} \\
(-6.64)\end{array}$ & $\begin{array}{c}-0.392 * * * \\
(-13.95)\end{array}$ & $\begin{array}{c}-0.246 * * * \\
(-6.62)\end{array}$ & $\begin{array}{c}-0.404 * * * \\
(-14.16)\end{array}$ & $\begin{array}{c}-0.245 * * * \\
(-6.63)\end{array}$ \\
\hline INVREC & $\begin{array}{c}0.443 * * * \\
(9.05)\end{array}$ & $\begin{array}{c}0.209 * * * \\
(2.93)\end{array}$ & $\begin{array}{c}0.421 * * * \\
(8.52)\end{array}$ & $\begin{array}{c}0.192 * * * \\
(2.70)\end{array}$ & $\begin{array}{c}0.441 * * * \\
(9.02)\end{array}$ & $\begin{array}{c}0.207 * * * \\
(2.88)\end{array}$ & $\begin{array}{c}0.420 * * * \\
(8.51)\end{array}$ & $\begin{array}{c}0.195^{* * *} \\
(2.73)\end{array}$ \\
\hline LOSS & $\begin{array}{c}0.101 * * * \\
(7.93)\end{array}$ & $\begin{array}{c}0.105^{* * * *} \\
(4.53)\end{array}$ & $\begin{array}{c}0.107 * * * \\
(8.25)\end{array}$ & $\begin{array}{c}0.108 * * * \\
(4.66)\end{array}$ & $\begin{array}{c}0.101 * * * \\
(7.90)\end{array}$ & $\begin{array}{c}0.107 * * * \\
(4.61)\end{array}$ & $\begin{array}{c}0.107 * * * \\
(8.23)\end{array}$ & $\begin{array}{c}0.109^{* * *} \\
(4.70)\end{array}$ \\
\hline INTACCR & $\begin{array}{c}0.018 * * * \\
(4.04)\end{array}$ & $\begin{array}{c}0.019 * * \\
(2.41)\end{array}$ & $\begin{array}{c}0.018 * * * \\
(3.95)\end{array}$ & $\begin{array}{c}0.019 * * \\
(2.41)\end{array}$ & $\begin{array}{c}0.018 * * * \\
(4.06)\end{array}$ & $\begin{array}{c}0.019 * * \\
(2.38)\end{array}$ & $\begin{array}{c}0.018 * * * \\
(3.94)\end{array}$ & $\begin{array}{c}0.019 * * \\
(2.40)\end{array}$ \\
\hline$M B$ & $\begin{array}{c}0.006 * * * \\
(5.32)\end{array}$ & $\begin{array}{l}0.003 \\
(1.41)\end{array}$ & $\begin{array}{c}0.006 * * * \\
(5.44)\end{array}$ & $\begin{array}{l}0.003 \\
(1.46)\end{array}$ & $\begin{array}{c}0.006^{* * * *} \\
(5.29)\end{array}$ & $\begin{array}{l}0.003 \\
(1.44)\end{array}$ & $\begin{array}{c}0.006 * * * \\
(5.41)\end{array}$ & $\begin{array}{l}0.003 \\
(1.46)\end{array}$ \\
\hline IFRS & $\begin{array}{c}0.480 * * * \\
(17.02)\end{array}$ & $\begin{array}{c}0.226 * * * \\
(3.93)\end{array}$ & $\begin{array}{c}0.361 * * * \\
(13.43)\end{array}$ & $\begin{array}{c}0.177 * * * \\
(3.17)\end{array}$ & $\begin{array}{c}0.474 * * * \\
(16.77)\end{array}$ & $\begin{array}{c}0.229 * * * \\
(3.99)\end{array}$ & $\begin{array}{c}0.357 * * * \\
(13.22)\end{array}$ & $\begin{array}{c}0.183 * * * \\
(3.29)\end{array}$ \\
\hline$F S R$ & $\begin{array}{c}0.318^{* * *} \\
(11.08)\end{array}$ & $\begin{array}{c}0.295^{* * * *} \\
(5.60)\end{array}$ & $\begin{array}{c}0.319 * * * \\
(10.72)\end{array}$ & $\begin{array}{c}0.298 * * * \\
(5.65)\end{array}$ & $\begin{array}{c}0.315^{* * * *} \\
(10.97)\end{array}$ & $\begin{array}{c}0.293 * * * \\
(5.58)\end{array}$ & $\begin{array}{c}0.316 * * * \\
(10.62)\end{array}$ & $\begin{array}{c}0.297 * * * \\
(5.63)\end{array}$ \\
\hline NBS & $0.168 * * *$ & $0.131 * * *$ & $0.155^{* * *}$ & $0.122 * * *$ & $0.168 * * *$ & $0.132 * * *$ & $0.155^{* * *}$ & $0.125 * * *$ \\
\hline
\end{tabular}




\begin{tabular}{|c|c|c|c|c|c|c|c|c|}
\hline \multirow{2}{*}{$N G S$} & $(10.43)$ & $(4.03)$ & $(9.47)$ & (3.74) & $(10.47)$ & $(4.06)$ & $(9.50)$ & $\begin{array}{l}(3.84) \\
0.73 * * *\end{array}$ \\
\hline & $\begin{array}{c}0.180 * * * \\
(9.42)\end{array}$ & $\begin{array}{c}0.176 * * * \\
(4.90)\end{array}$ & $\begin{array}{c}0.169 * * * \\
(8.68)\end{array}$ & $\begin{array}{c}0.173 * * * \\
(4.86)\end{array}$ & $\begin{array}{c}0.180^{* * *} \\
(9.43)\end{array}$ & $\begin{array}{c}0.176 * * * \\
(4.91)\end{array}$ & $\begin{array}{c}0.170 * * * \\
(8.71)\end{array}$ & $\begin{array}{c}0.173 * * * \\
(4.83)\end{array}$ \\
\hline \multicolumn{9}{|c|}{ Section C: Country-level control variables } \\
\hline$L G D P$ & $\begin{array}{c}0.182 * * * \\
(9.62)\end{array}$ & $\begin{array}{c}0.228 * * * \\
(3.81)\end{array}$ & $\begin{array}{c}0.253 * * * \\
(14.65)\end{array}$ & $\begin{array}{c}0.207 * * * \\
(3.44)\end{array}$ & $\begin{array}{c}0.180 * * * \\
(9.49)\end{array}$ & $\begin{array}{c}0.196 * * * \\
(3.26)\end{array}$ & $\begin{array}{c}0.254 * * * \\
(14.67)\end{array}$ & $\begin{array}{c}0.186 * * * \\
(3.06)\end{array}$ \\
\hline$L O G M K T$ & $\begin{array}{c}0.346 * * * \\
(37.67)\end{array}$ & $\begin{array}{c}0.365^{* * * *} \\
(13.41)\end{array}$ & $\begin{array}{c}0.353 * * * \\
(35.90)\end{array}$ & $\begin{array}{c}0.393 * * * \\
(15.86)\end{array}$ & $\begin{array}{c}0.350 * * * \\
(37.79)\end{array}$ & $\begin{array}{c}0.380 * * * \\
(14.24)\end{array}$ & $\begin{array}{c}0.354 * * * \\
(36.28)\end{array}$ & $\begin{array}{c}0.401 * * * \\
(16.30)\end{array}$ \\
\hline Constant & $\begin{array}{c}-4.086 * * * * \\
(-14.28)\end{array}$ & $\begin{array}{c}-5.571 * * * \\
(-6.37)\end{array}$ & $\begin{array}{c}-4.107 * * * \\
(-17.01)\end{array}$ & $\begin{array}{c}-5.117 * * * \\
(-6.21)\end{array}$ & $\begin{array}{c}-3.930 * * * \\
(-13.74)\end{array}$ & $\begin{array}{c}-4.822 * * * \\
(-5.62)\end{array}$ & $\begin{array}{c}-4.050 * * * \\
(-17.13)\end{array}$ & $\begin{array}{c}-4.435 * * * \\
(-5.79)\end{array}$ \\
\hline
\end{tabular}

Section D: Test Statistics

$\mathrm{Chi}^{2}$-statistics (p-value) for testing Big 4 vs. Non-Big 4

\begin{tabular}{|c|c|c|c|c|c|c|c|c|}
\hline CONC & \multicolumn{2}{|c|}{$\begin{array}{l}8.39 * * * \\
(0.0038)\end{array}$} & \multicolumn{2}{|c|}{$\begin{array}{l}7.60 * * * \\
(0.0058)\end{array}$} & \multicolumn{2}{|c|}{$\begin{array}{c}4.64 * * \\
(0.0312)\end{array}$} & \multicolumn{2}{|c|}{$\begin{array}{c}5.26^{* *} \\
(0.0218)\end{array}$} \\
\hline$L A W$ & \multicolumn{2}{|c|}{$\begin{array}{c}0.84 \\
(0.3589)\end{array}$} & \multicolumn{2}{|c|}{1.85} & \multicolumn{2}{|c|}{0.08} & \multicolumn{2}{|c|}{0.52} \\
\hline$C O N C * L A W$ & \multicolumn{2}{|c|}{$\begin{array}{l}7.00 * * * * \\
(0.0081)\end{array}$} & \multicolumn{2}{|c|}{$\begin{array}{c}6.42^{* *} \\
(0.0113)\end{array}$} & \multicolumn{2}{|c|}{$\begin{array}{c}3.74 * \\
(0.0530)\end{array}$} & \multicolumn{2}{|c|}{$\begin{array}{c}4.27 * * \\
(0.0388)\end{array}$} \\
\hline Observations & 36,702 & 7,212 & 36,702 & 7,212 & 36,702 & 7,212 & 36,702 & 7,212 \\
\hline Adjusted R-squared & 0.809 & 0.732 & 0.806 & 0.732 & 0.809 & 0.731 & 0.806 & 0.731 \\
\hline Year Indicator & yes & yes & yes & yes & yes & yes & Yes & yes \\
\hline Industry Indicator & yes & yes & yes & yes & yes & yes & Yes & yes \\
\hline
\end{tabular}

This table presents the regression results to test H3 using Eq. (2). From Columns (1) to (4), we measure audit market concentration with $\mathrm{CONCl}$ whereas we use CONC2 from Columns (5) to (8). In Columns (1), (2), (5) and (6), we measure the strength of legal regime with $L A W 1$. In columns (3), (4), (7) and (8), we measure the strength of legal regime with $L A W 2$. In columns with odd numbers, the results are for the clients of the Big 4 auditors whereas, in columns with even numbers, the results are for the clients of non-Big 4 auditors. See the Appendix for detailed variable definitions. The numbers in parentheses represent $\mathrm{t}$-statistics based on standard errors clustered by firm. $* * *, * *$, and $*$ indicate statistical significance at the $1 \%, 5 \%$, and $10 \%$ levels, respectively. We do not separately tabulate the results using Eq. (1) because they can be inferred from the tabulated results. 
Table 5. Sensitivity Analyses

Panel A. The Association Between Audit Market Concentration, Legal Regime, and Audit Fees

\begin{tabular}{|c|c|c|c|c|c|c|c|c|}
\hline & \multicolumn{2}{|c|}{ WLS } & \multicolumn{2}{|c|}{$\begin{array}{c}\text { (2) } \\
\text { Use of country-year } \\
\text { concentration measure }\end{array}$} & \multicolumn{2}{|c|}{$\begin{array}{c}\text { (3) } \\
\text { Use of 2-digit } \\
\text { industry classification }\end{array}$} & \multicolumn{2}{|c|}{$\begin{array}{l}(4) \\
\text { Propensity score } \\
\text { matching analysis }\end{array}$} \\
\hline & $(1-1)$ & $(1-2)$ & $(2-1)$ & $(2-2)$ & $(3-1)$ & $(3-2)$ & $(4-1)$ & $(4-2)$ \\
\hline CONC1 & $\begin{array}{l}-0.003 \\
(-0.04)\end{array}$ & $\begin{array}{c}1.815^{* * * *} \\
(3.83)\end{array}$ & $\begin{array}{c}1.142 * * * \\
(7.63)\end{array}$ & $\begin{array}{c}5.854 * * * \\
(5.50)\end{array}$ & $\begin{array}{c}0.216^{* * * *} \\
(4.76)\end{array}$ & $\begin{array}{c}2.049 * * * \\
(5.87)\end{array}$ & $\begin{array}{c}0.383 * * * \\
(4.44)\end{array}$ & $\begin{array}{c}2.835 * * * \\
\quad(4.15)\end{array}$ \\
\hline$L A W 1$ & $\begin{array}{c}1.198 * * * \\
(8.17)\end{array}$ & $\begin{array}{c}2.318 * * * \\
(7.07)\end{array}$ & $\begin{array}{c}1.639 * * * \\
(14.19)\end{array}$ & $\begin{array}{c}4.000 * * * \\
(7.58)\end{array}$ & $\begin{array}{c}1.298 * * * \\
(10.52)\end{array}$ & $\begin{array}{c}2.523 * * * \\
(9.85)\end{array}$ & $\begin{array}{c}1.171 * * * \\
(6.85)\end{array}$ & $\begin{array}{c}2.681 * * * \\
(6.15)\end{array}$ \\
\hline CONC1 1 *LAW1 & & $\begin{array}{c}-2.622 * * * \\
(-3.98)\end{array}$ & & $\begin{array}{c}-7.116 * * * \\
(-4.53)\end{array}$ & & $\begin{array}{c}-2.443 * * * \\
(-5.33)\end{array}$ & & $\begin{array}{c}-3.352 * * * \\
(-3.60)\end{array}$ \\
\hline Observations & 43,914 & 43,914 & 42,117 & 42,117 & 39,301 & 39,301 & 13,852 & 13,852 \\
\hline Adjusted R-squared & 0.750 & 0.750 & 0.823 & 0.823 & 0.826 & 0.827 & 0.756 & 0.757 \\
\hline Controls & Included & Included & Included & Included & Included & Included & Included & Included \\
\hline Year indicator & Included & Included & Included & Included & Included & Included & Included & Included \\
\hline Industry indicator & Included & Included & Included & Included & Included & Included & Included & Included \\
\hline
\end{tabular}


Panel B. The Association Between Audit Market Concentration, Legal Regime, and Audit Fees: Big 4 Versus Non-Big 4 Auditors

\begin{tabular}{|c|c|c|c|c|c|c|c|c|}
\hline \multirow[b]{2}{*}{ Auditors } & \multicolumn{2}{|c|}{ WLS } & \multicolumn{2}{|c|}{$\begin{array}{c}\text { (2) } \\
\text { Use of country-year } \\
\text { concentration measure }\end{array}$} & \multicolumn{2}{|c|}{$\begin{array}{c}\text { (3) } \\
\text { Use of 2-digit } \\
\text { industry classification }\end{array}$} & \multicolumn{2}{|c|}{$\begin{array}{c}(4) \\
\text { Propensity score } \\
\text { matching analysis }\end{array}$} \\
\hline & $\begin{array}{l}(1-1) \\
\text { Big } 4\end{array}$ & $\begin{array}{c}(1-2) \\
\text { Non-Big } 4\end{array}$ & $\begin{array}{l}\text { (2-1) } \\
\text { Big } 4\end{array}$ & $\begin{array}{c}(2-2) \\
\text { Non-Big } 4\end{array}$ & $\begin{array}{l}(3-1) \\
\text { Big } 4\end{array}$ & $\begin{array}{c}(3-2) \\
\text { Non-Big } 4\end{array}$ & $\begin{array}{l}(4-1) \\
\text { Big } 4\end{array}$ & $\begin{array}{c}(4-2) \\
\text { Non-Big } 4\end{array}$ \\
\hline \multicolumn{9}{|c|}{ Section A: Test variabl } \\
\hline CONCI & $\begin{array}{c}1.367 * * * \\
(2.78)\end{array}$ & $\begin{array}{c}5.911 * * * \\
(4.34)\end{array}$ & $\begin{array}{c}5.562 * * * \\
(4.90)\end{array}$ & $\begin{array}{c}20.933 * * * \\
(3.79)\end{array}$ & $\begin{array}{c}1.781 * * * \\
(4.92)\end{array}$ & $\begin{array}{c}3.087 * * * \\
(3.26)\end{array}$ & $\begin{array}{c}1.972 * * * \\
(2.69)\end{array}$ & $\begin{array}{c}4.961 * * * \\
(4.17)\end{array}$ \\
\hline$L A W 1$ & $\begin{array}{c}2.106^{* * * *} \\
(6.07)\end{array}$ & $\begin{array}{c}3.822 * * * \\
(4.77)\end{array}$ & $\begin{array}{c}3.964 * * * \\
(7.02)\end{array}$ & $\begin{array}{c}9.724 * * * \\
(3.96)\end{array}$ & $\begin{array}{c}2.444 * * * \\
(9.13)\end{array}$ & $\begin{array}{c}2.047 * * * \\
(2.82)\end{array}$ & $\begin{array}{c}2.430 * * * \\
(5.20)\end{array}$ & $\begin{array}{c}2.856 * * * \\
(3.53)\end{array}$ \\
\hline$C O N C 1 * L A W 1$ & $\begin{array}{c}-2.029 * * * \\
(-2.95)\end{array}$ & $\begin{array}{c}-8.017 * * * \\
(-4.53)\end{array}$ & $\begin{array}{c}-6.781 * * * \\
(-4.02)\end{array}$ & $\begin{array}{c}-26.833 * * * \\
(-3.72)\end{array}$ & $\begin{array}{c}-2.093 * * * \\
(-4.41)\end{array}$ & $\begin{array}{c}-3.727 * * * \\
(-2.99)\end{array}$ & $\begin{array}{c}-2.286^{* *} \\
(-2.27)\end{array}$ & $\begin{array}{c}-5.988 * * * \\
(-3.70)\end{array}$ \\
\hline
\end{tabular}

Section B: Test statistics

$\mathrm{Chi}^{2}$-statistics (p-value) for testing Big 4 vs. Non-Big 4

$\begin{array}{lc}\text { CONC1 } & 9.98 * * * \\ & (0.0016) \\ L A W 1 & 3.92 * * \\ & (0.0477) \\ C O N C 1 * L A W 1 & 10.09 * * * \\ & (0.0015)\end{array}$

\section{$7.54 * * *$ \\ $(0.0060)$ \\ 5.28** \\ (0.0215) \\ $7.41 * * *$ \\ (0.0065)}

1.70
$(0.1926)$
0.27
$(0.6056)$
1.53
$(0.2165)$

1.70

0.27

$(0.2165)$

$$
\begin{gathered}
4.60 * * \\
(0.0320) \\
0.21 \\
(0.6482) \\
3.78 * \\
(0.0518)
\end{gathered}
$$

\begin{tabular}{|c|c|c|c|c|c|c|c|c|}
\hline Observations & 36,702 & 7,212 & 35,037 & 7,080 & 32,555 & 6,746 & 6,926 & 6,926 \\
\hline Adjusted R-squared & 0.758 & 0.605 & 0.818 & 0.740 & 0.820 & 0.745 & 0.781 & 0.732 \\
\hline Controls & Included & Included & Included & Included & Included & Included & Included & Included \\
\hline Year indicator & Included & Included & Included & Included & Included & Included & Included & Included \\
\hline Industry indicator & Included & Included & Included & Included & Included & Included & Included & Included \\
\hline
\end{tabular}

This table presents the results of various sensitivity analyses. Panel A presents the results on $\mathrm{H} 1$ and $\mathrm{H} 2$, while Panel B presents the results on $\mathrm{H} 3$. In this table, we use CONC1 and LAWI to measure audit market concentration and strength of legal regime, respectively. Column (1) reports the results of the weighted least square (WLS) regression assigning an equal weight to each country. Column (2) reports the results measuring audit market concentration at 
each country-year basis, without considering industry. Columns (3) reports the results measuring audit market concentration based on the 2-digit SIC industry codes. Column (4) reports the results of the analyses using propensity matched samples for auditor choice. See the Appendix for detailed variable definitions. The numbers in parentheses represent $\mathrm{t}$-statistics based on standard errors clustered by firm. $* * *, * *$, and $*$ indicate statistical significance at the $1 \%, 5 \%$, and $10 \%$ levels, respectively. 